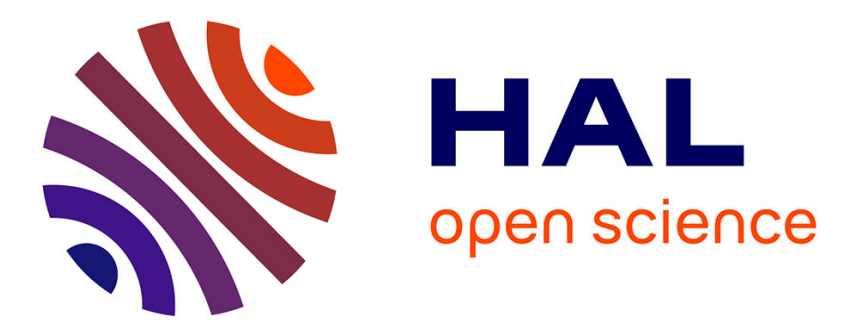

\title{
Active basement uplift of Sierra Pie de Palo (Northwestern Argentina): Rates and inception from10Be cosmogenic nuclide concentrations
}

Lionel Siame, Michel Sébrier, O Bellier, D. Bourles, C. Costa, E.A. Ahumada, C.E. Gardini, H. Cisneros

\section{To cite this version:}

Lionel Siame, Michel Sébrier, O Bellier, D. Bourles, C. Costa, et al.. Active basement uplift of Sierra Pie de Palo (Northwestern Argentina): Rates and inception from10Be cosmogenic nuclide concentrations. Tectonics, 2015, 34 (6), pp.1129-1153. 10.1002/2014TC003771 . hal-01458841

\section{HAL Id: hal-01458841 \\ https://hal-amu.archives-ouvertes.fr/hal-01458841}

Submitted on 5 Oct 2018

HAL is a multi-disciplinary open access archive for the deposit and dissemination of scientific research documents, whether they are published or not. The documents may come from teaching and research institutions in France or abroad, or from public or private research centers.
L'archive ouverte pluridisciplinaire HAL, est destinée au dépôt et à la diffusion de documents scientifiques de niveau recherche, publiés ou non, émanant des établissements d'enseignement et de recherche français ou étrangers, des laboratoires publics ou privés. 


\section{Active basement uplift of Sierra Pie de Palo (Northwestern Argentina): Rates and inception from10Be cosmogenic nuclide concentrations}

Lionel Siame, Michel Sébrier, O. Bellier, D. Bourlès, C. Costa, E.A. Ahumada, C.E. Gardini, H. Cisneros

\section{To cite this version:}

Lionel Siame, Michel Sébrier, O. Bellier, D. Bourlès, C. Costa, et al.. Active basement uplift of Sierra Pie de Palo (Northwestern Argentina): Rates and inception from10Be cosmogenic nuclide concentrations. Tectonics, American Geophysical Union (AGU), 2015, 34 (6), pp.1129-1153.

$<10.1002 / 2014$ TC003771 $>$. <hal-01458841>

\section{HAL Id: hal-01458841 \\ https://hal-amu.archives-ouvertes.fr/hal-01458841}

Submitted on 5 Oct 2018

HAL is a multi-disciplinary open access archive for the deposit and dissemination of scientific research documents, whether they are published or not. The documents may come from teaching and research institutions in France or abroad, or from public or private research centers.
L'archive ouverte pluridisciplinaire HAL, est destinée au dépôt et à la diffusion de documents scientifiques de niveau recherche, publiés ou non, émanant des établissements d'enseignement et de recherche français ou étrangers, des laboratoires publics ou privés. 


\section{RESEARCH ARTICLE}

10.1002/2014TC003771

Key Points:

- Tectonic rates for basement uplift

- Magnitude and regional denudation pattern

- Scenario from basement exhumation to uplift for the Sierra Pie de Palo

Supporting Information:

- Tables S1-S4

- Text S1 and Captions of Tables S1-S4

Correspondence to:

L. L. Siame,

siame@cerege.fr

Citation:

Siame, L. L., M. Sébrier, O. Bellier, D. Bourlès, C. Costa, E. A. Ahumada, C. E. Gardini, and H. Cisneros (2015), Active basement uplift of Sierra Pie de Palo (Northwestern Argentina): Rates and inception from ${ }^{10} \mathrm{Be}$ cosmogenic nuclide concentrations, Tectonics, 34, 1129-1153, doi:10.1002/2014TC003771.

Received 30 OCT 2014 Accepted 1 MAY 2015

Accepted article online 26 MAY 2015 Published online 6 JUN 2015

\section{Active basement uplift of Sierra Pie de Palo (Northwestern Argentina): Rates and inception from ${ }^{10} \mathrm{Be}$ cosmogenic nuclide concentrations}

\author{
Lionel L. Siame ${ }^{1,2,3}$, Michel Sébrier ${ }^{4}$, Olivier Bellier ${ }^{1}$, Didier Bourlès ${ }^{1}$, Carlos Costa ${ }^{5}$, \\ Emilio A. Ahumada ${ }^{5}$, Carlos E. Gardini ${ }^{5}$, and Hector Cisneros ${ }^{5}$ \\ ${ }^{1}$ Aix-Marseille Université, CNRS-IRD-Collège de France, UM34 Centre Européen de Recherche et d'Enseignement des \\ Géosciences I'Environnement, Technopôle de I'Arbois, Aix-en-Provence, France, ${ }^{2}$ Institute of Earth Sciences, Academia \\ Sinica, Taipei, Taiwan, ${ }^{3}$ Institute of Geophysics, National Central University, Chungli, Taiwan, ${ }^{4}$ Institut des Sciences de la \\ Terre de Paris UMR 7193, CNRS, Université Pierre et Marie Curie, Paris, France, ${ }^{5}$ Department of Geology, Universidad \\ Nacional de San Luis, San Luis, Argentina
}

\begin{abstract}
Quaternary tectonic and denudation rates are investigated for an actively growing basement anticline: the Sierra Pie de Palo range, which belongs to the Andean foreland of Northwestern Argentina $\left(28^{\circ} \mathrm{S}-33^{\circ} \mathrm{S}\right)$. In this study, a detailed morphometric analysis of the topography is combined with in situ-produced cosmogenic ${ }^{10}$ Be concentrations measured in (1) surface boulders abandoned on alluvial terraces affected by fault activity (along the north bounding fault) and growth of the basement fold (along the southeastern border), (2) bedrock outcrops corresponding to an exhumed and folded, regional erosion surface, and (3) fluvial sediments sampled at the outlets of several watersheds. Along the eastern and northern borders of the range, incision and uplift rates have been estimated at approximately 0.5 and $1 \mathrm{~mm} / \mathrm{yr}$ when integrated on Holocene and Pleistocene time scales, in close agreement with both long-term (structural and basin evolution data) and short-term (GPS-derived velocity field) analyses. Cosmogenic-derived denudation and uplift rates combined with geomorphic characteristics of watersheds and river channels allows estimating the onset of the uplift at 4-6 Ma, followed by a more recent period of topographic rejuvenation at roughly 1-2 Ma, probably synchronous with steepening of the eastern and northern flanks of the anticline.
\end{abstract}

\section{Introduction}

Quantification of relief creation is an important step in studying mountain building processes. Because relief development is mainly the result of complex interactions between tectonics and climate [Molnar, 2009], examining relief changes with time not only requires quantification of tectonic deformation but also insights into the location and magnitude of erosional processes [Champagnac et al., 2014; Godard et al., 2014]. In active tectonic settings, faults grow by repeated coseismic displacements, increasing their cumulative offsets with time. In compressional domains, most reverse or thrust faults are commonly associated with folds; their lateral propagation and vertical movement produce deformation of the Earth's surface in the form of flexures, which can be directly used to identify major areas of crustal or lithospheric deformation. Where reverse or thrust faults are hidden or even blind, the topographic disturbances caused by fold growth may be identified in the landscape, such as in the drainage network incising the uplifting structures [Molnar et al., 1994; Jackson et al., 1996]. However, there are only few cases for which the growth rates have been successfully determined using a well-constrained chronological framework [e.g., Jackson et al., 2002].

Located in the Andean foreland of Northwestern Argentina, the Sierra Pie de Palo (SPDP) range is a case study to quantify relief creation. The SPDP is an active basement anticline, the growth of which is controlled by crustal-scale reverse faults [Régnier et al., 1992; Smalley et al., 1993; Zapata, 1998; Ramos et al., 2002] and evidenced by the folding of a regional erosional surface exhumed from the Andean foreland Bermejo basin [Jordan et al., 1989]. In this region, a desert climate combined with high rates of tectonic deformation provides high-preservation potential of deformed geomorphic features. Indeed, the growth of the SPDP interfered with the impact of fluvial activity, resulting in stepped fluvial terraces that are uplifted, tilted, and/or faulted. Dating such geomorphic features using cosmic ray exposure (CRE) techniques has become a common method to estimate rates of tectonic deformation [e.g., Gosse and Phillips, 2001]. Even if this approach has been applied 
to several sectors in this Andean region [Siame et al., 1997, 2002; Meigs et al., 2006; Schmidt et al., 2011, 2012; Hedrick et al., 2013], this area still lacks of a well-constrained chronological framework for alluvial deposition and abandonment.

In this study, we present new in situ-produced cosmogenic ${ }^{10}$ Be data from this actively deforming and arid region of Northwestern Argentina. Thanks to a combination of detailed geomorphic and topographic analyses with CRE dating and quantification of denudation rates, we investigated the Plio-Quaternary uplift history of the SPDP. In situ-produced ${ }^{10}$ Be concentrations were measured in (1) surface boulders abandoned on stepped alluvial surfaces affected by fault activity along the eastern and northern borders of the SPDP, (2) bedrock outcrops corresponding to the exhumed regional erosional surface, and (3) fluvial sediments sampled at the outlets of several watersheds that incised this erosional surface. The obtained results constrain the incision rates and provide minimum estimates on the Holocene and Pleistocene uplift rates associated with the growth of the SPDP. We also determined catchment-wide denudation rates that are 1 order of magnitude higher than bedrock denudation rates. Cosmogenic-derived denudation and uplift rates combined with geomorphic characteristics of watersheds and river channels allows estimating the onset of the uplift at 4-6 Ma, followed by a more recent period of topographic rejuvenation at roughly 1-2 Ma, probably synchronous with steepening of the eastern and northern flanks of the anticline.

\section{Regional Setting of the Andean Foreland of Northwestern Argentina}

The Andean foreland of Northwestern Argentina $\left(28^{\circ} \mathrm{S}-33^{\circ} \mathrm{S}\right)$ is located above the flat subduction of the Nazca Plate beneath the South American lithosphere [Cahill and Isacks, 1992; Yáñez et al., 2001; Anderson et al., 2007] ongoing at a rate of about $8 \mathrm{~cm} / \mathrm{yr}$ with an azimuth of $\mathrm{N74}{ }^{\circ} \mathrm{E}$ (Figure 1a) [DeMets et al., 1990]. In this region, two compressional, opposite verging structural provinces are facing: the east verging, thin-skinned Argentine Precordillera (AP) fold-and-thrust belt and the west verging, thick-skinned Sierras Pampeanas (SP) basement uplifts (Figures 1b and 1c) [Ortiz and Zambrano, 1981; Ramos et al., 2002; Vergés et al., 2007].

The progressive shallowing of the Nazca slab induced a change in the geochemical properties of the Neogene volcanic rocks and subsequently the cessation of volcanic activity at roughly 7-6 Ma in the AP [Kay and Abbruzzi, 1996] and between 4.7 and $2 \mathrm{Ma}$ in the SP [Gordillo and Linares, 1981; Kay et al., 1991; Kay and Gordillo, 1994; Urbina et al., 1997]. It also induced enhanced plate coupling [Jordan et al., 1983; Jordan and Allmendinger, 1986; Smalley et al., 1993] as well as thermal weakness of the crust associated with eastward migration of the magmatic arc [Ramos et al., 2002], which have long been considered to be responsible for thick-skinned basement uplifts in the SP.

In the AP, the timing of the craton-ward fold-and-thrust belt development has been determined through detailed magnetostratigraphic and growth strata studies of the synorogenic materials deposited within intramountain basins and the Bermejo Valley [Jordan et al., 1993; Zapata and Allmendinger, 1996]. In the Western $\mathrm{AP}$, this deformation started at 19-20 Ma and propagated to the Central AP from 10-12 Ma to roughly 5 Ma [Jordan et al., 1993; Zapata and Allmendinger, 1996; Perucca and Onorato, 2011]. During the last 5 Ma, regional deformation concentrated along the west verging Eastern AP thrusts and folds, synchronous with the basement uplifts in the western SP [Jordan et al., 1993; Zapata and Allmendinger, 1996; Ramos et al., 2002].

In the northern SP $\left(28^{\circ} \mathrm{S}\right)$, stratigraphic data [Strecker, 1987] and apatite fission track [Coughlin et al., 1998] studies allows bracketing the main uplift of the Sierra Aconquija between 7.6-6.0 and 4.0-3.4 Ma [Ramos et al., 2002]. Farther south $\left(29^{\circ} \mathrm{S}\right)$, magnetostratigraphic [Tripaldi et al., 2011] and isotopic [Tosselli, 1996; Losada-Calderón et al., 1994] studies suggest an uplift inception between 4.5 and 4.2 Ma in the Sierra Famatina [Ramos et al., 2002]. To the south (Sierra de Còrdoba and Sierra de Chepes), ages of volcanic series (Figure 1b) [Kay and Abbruzzi, 1996; Kay and Gordillo, 1994; Gordillo and Linares, 1981] suggests an uplift timing between 6.0 and 5.5 Ma [Ramos et al., 2002].

For the SPDP, the thermal modeling of apatite fission tracks and (U-Th)/He ages supports an onset of final cooling and exhumation of this western Pampean range between Cretaceous and Paleogene time (at about $60 \mathrm{Ma}$ ), in relation with an early phase of Andean compression [Löbens et al., 2013b]. These authors also proposed that the relief associated with the SPDP may have existed since the Mesozoic [e.g., Carignano et al., 1999]. Conversely, Ramos et al. [2002] suggested that the exhumation of the SPDP started at roughly 3 Ma (Figure $1 \mathrm{~b}$ ), controlled at depth by a midcrustal wedge, with average shortening and uplift rates of about 4 and $1 \mathrm{~mm} / \mathrm{yr}$, respectively. Finally, the exhumation of this range has alternatively been described as a result 

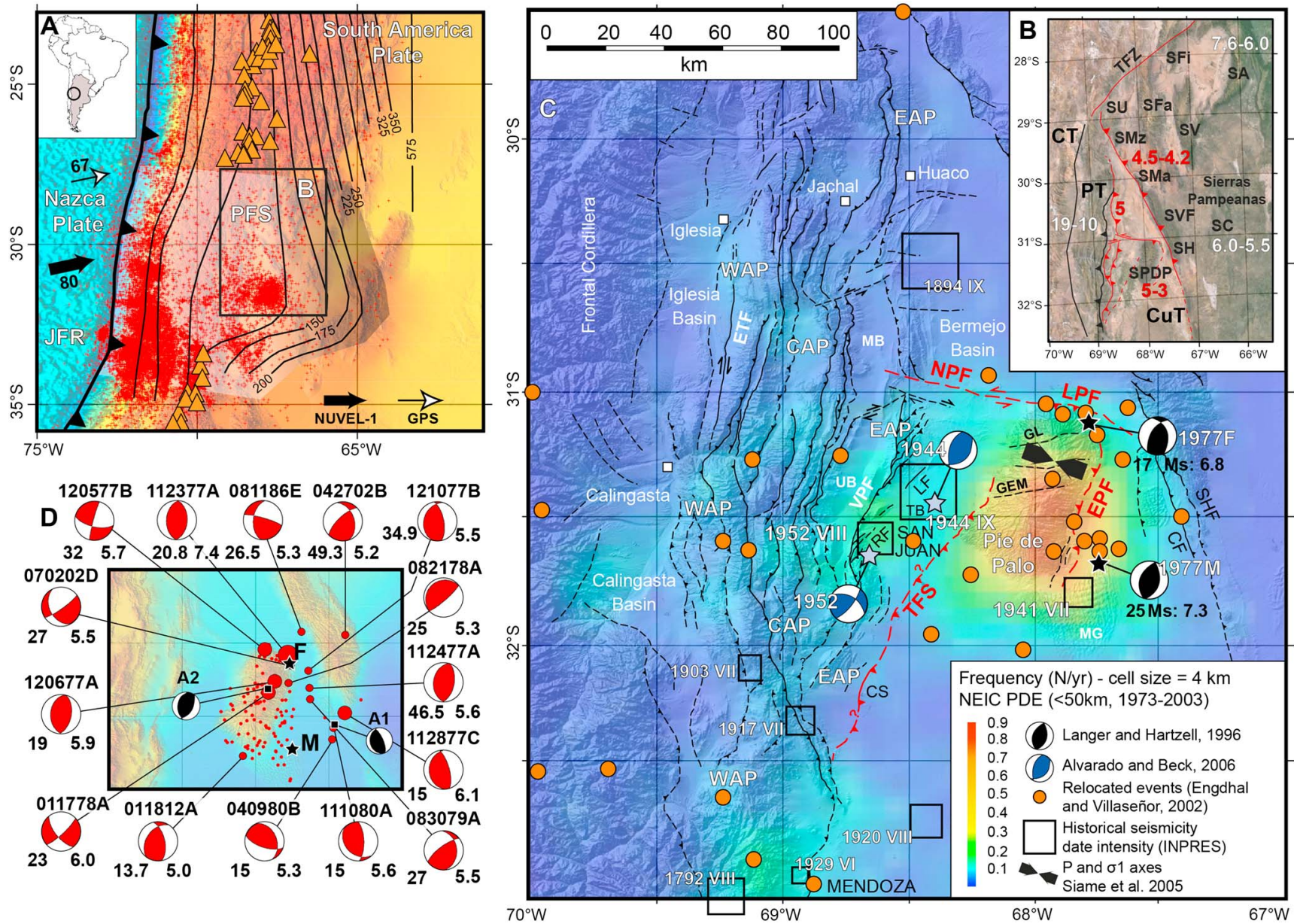

Figure 1. (a) Geodynamic setting of Central Andes at $30^{\circ} \mathrm{S}$. Red dots show the earthquake distribution (U.S. Geological Survey, National Earthquake Information Center; Preliminary Determination of Epicenter catalog, 1973 to 2014, depth $\leq 70 \mathrm{~km}$, magnitude $\geq 4.0$ ). Yellow solid triangles correspond to Plio-Quaternary and active volcanoes. Black and white arrows represent the relative convergence of the Nazca and South American Plates following NUVEL-1 [DeMets et al., 1990] and continuous GPS observation [Brooks et al., 2003], respectively. Numbers are given in mm/yr. Isodepth contours of the subducted Nazca Plate are shown after Cahill and Isacks [1992]. (b) Schematic regional structural map locating the Argentine Precordillera (AP) and the western Sierras Pampeanas (SP). White and red numbers (given in Ma) refer to inception of deformation [Jordan et al., 1993; Zapata and Allmendinger, 1996; Ramos et al., 2002]. (c) Structural regional map of AP and SP from SPOT and Landsat image analysis (modified after Siame et al. [2005]). Structures bounding the Sierra Pie de Palo (SPDP) are highlighted in red. Seismicity frequency grid derived from the Preliminary Determination Epicenter catalog $(100 \times 112,4 \mathrm{~km}$ large cells). Orange solid circles show the epicenter distribution of relocated seismic events [Engdahl and Villaseñor, 2002]. Black squares locate historical seismic events [Instituto Nacional de Prevencòn Sísmica (INPRES), 2014]. Light blue stars locate 15 January $1944\left(M_{w}=7.0\right)$ and 11 June $1952\left(M_{w}=6.8\right)$ earthquakes with focal mechanism solutions after Alvarado and Beck [2006]. Black solid stars locate foreshore and main shocks of the Caucete 23 November 1977 ( $M_{s}=7.4$ ) earthquake (focal mechanism solutions after Langer and Hartzell [1996]). (d) Close-up on the seismic activity of the SPDP. Large red solid circles locate the focal mechanism solutions from Harvard Centroid Moment Tensor Catalog (1973 to 2014). Lower left number indicates the focal depth $(\mathrm{km})$. Lower right number indicates the $M_{w}$ value. Locations are from the National Earthquake Information Center Preliminary Determination Epicenter catalog (U.S. Geological Survey). Red dots correspond to the seismicity recorded by Régnier et al. [1992]. Solid black stars locate the foreshock and the main shock of the 23 November 1977 Caucete earthquake [Langer and Hartzell, 1996]. Black solid squares locate the two main aftershocks [Kadinsky-Cade et al., 1985]. A1 and A2 aftershocks correspond to the Harvard events 112877C and 120677A, respectively. Keys: CAP, Central Argentine Precordillera; CF, Las Chacras Fault; CT, Chilean terrane; CuT, Cuyania terrane; EAP, Eastern Argentine Precordillera; EPF, Eastern Pie de Palo Fault; ETF, El Tigre Fault; GEM, Grande El Molle lineament; GL, Guayaupa-Lima lineament; JFR, Juan Fernandez Ridge; LF, La Laja Fault; LPF, Los Pajaritos Fault; MB, Matagusanos Basin; NPF: North Pie de Palo Fault; PFS, Pampean flat slab segment; PR, Perdida Ridge; PT, Precordilleran terrane; RF, Rinconada Fault; SA, Sierra Ambato; SC, Sierra de Chepes; SFa: Sierra de Famatina; SFi, Sierra Fiambalà; SH, Sierra de la Huerta; SHF, Sierra de la Huerta Fault; SMa: Sierra Morada; SMz, Sierra La Maz; SPDP, Sierra Pie de Palo; SU: Sierra Umango; SV, Sierra Velasco; SVF, Sierra de Valle Fértil; TFS, Tullum Fault System; TFZ, Tucumán fault zone; UB, Ullùm Basin; VPF, Villicùm-Pedernal Fault; WAP, western Argentine Precordillera. 

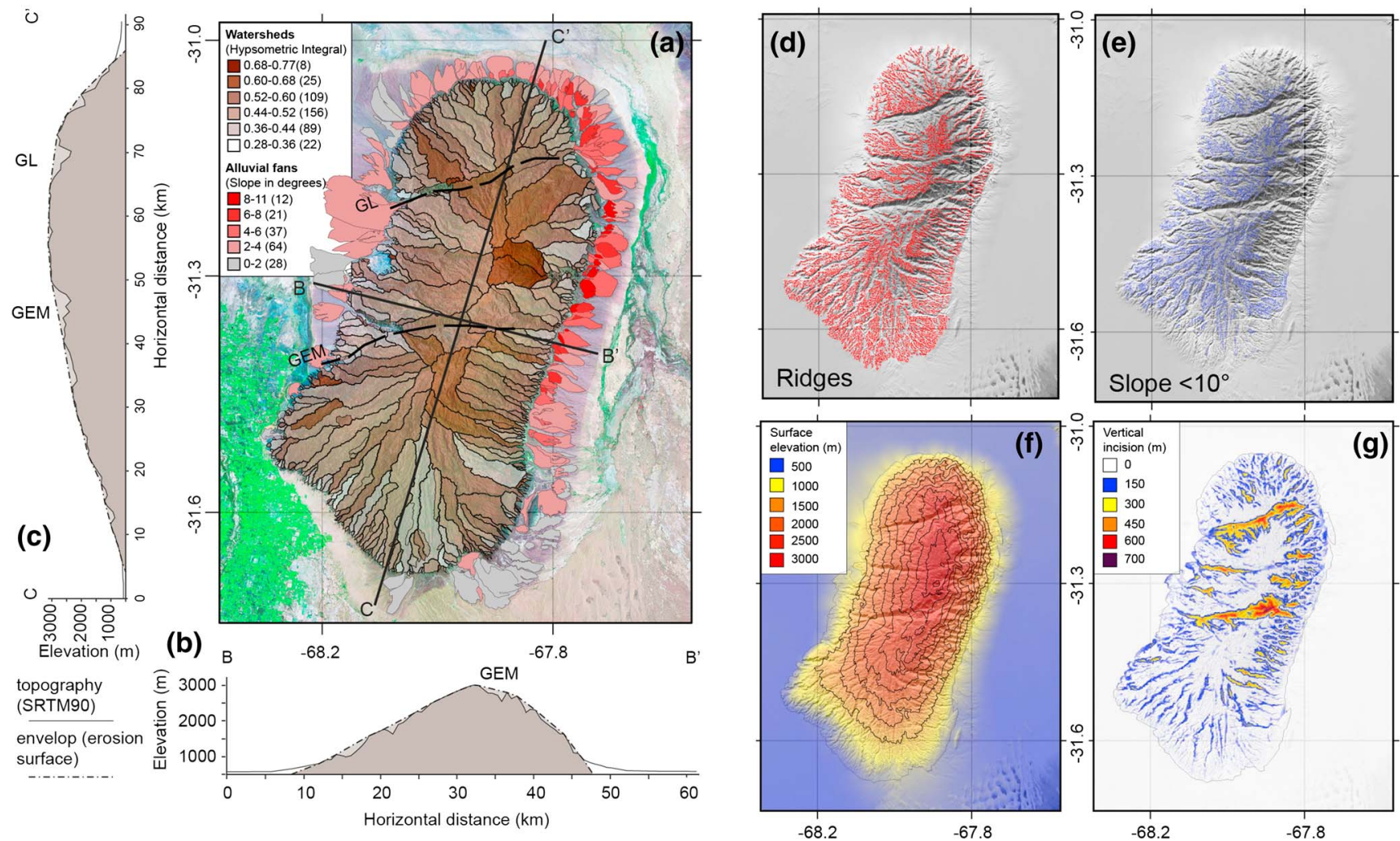

Figure 2. Geomorphic characteristics of the Sierra Pie de Palo. (a) Morphometric map of watersheds and piedmont deposits of the SPDP. Watersheds contours have been extracted from the SRTM90 DEM and are colored according to their hypsometric integral values. Alluvial fans have been mapped using Landsat and SPOT images, as well as SRTM90 DEM and derived slope grid. They are colored according to their slope values, averaged over alluvial area around the sample pixel. Both $\approx N-S\left(A-A^{\prime}\right)$ and $\approx E-W\left(B-B^{\prime}\right)$ topographic cross sections have been extracted from the SRTM90 DEM (thick solid lines) and the reconstructed regional erosion surface (thick dotted lines). (b) Map of the topographic ridges extracted from the SRTM90 DEM. (c) Map of the surfaces with local slope lower than $10^{\circ}$ extracted from the SRTM90 DEM. (d) DEM of the surface envelope of the SPDP (overlaid on the SRTM90 DEM) reconstructed by interpolation of the elevation points extracted from the ridges (Figure $2 \mathrm{~b}$ ) and low-slope areas (Figure 2d). (e) Map of the vertical incision derived from the subtraction of the envelope surface and the SRTM90 DEM. Spatial integration of these vertical incision values yield to the estimation of a minimum eroded volume of roughly $135 \mathrm{~km}^{3}$. Keys: GEM, Grande El Molle lineament; GL, Guayaupa-Lima lineament.

of cataclastic diapirism, which is proposed to produce dome-like topography at the surface due to lateral compressive forces and density differences [Vita-finzi, 2009].

Since roughly 150 years ago, this region experienced several large earthquakes, with the most recent events in $1944\left(M_{w} 7.0\right), 1952\left(M_{w} 6.8\right)$, and $1977\left(M_{w} 7.4\right)$ (Figure 1c) [Kadinsky-Cade et al., 1985; Langer and Hartzell, 1996; Alvarado et al., 2005; Alvarado and Beck, 2006; INPRES, 2014; Perucca and Vargas, 2014]. The regional high level of crustal seismic activity is characterized by hypocentral depths ranging between 5 and $35 \mathrm{~km}$ [Smalley et al., 1993]. Most historical and large instrumental earthquakes are located to the east of the AP, with two main clusters of seismic activity centered below the Tullùm-Ullùm basins, close to the San Juan city, and around the SPDP, particularly along its eastern edge (Figure 1c). This seismicity pattern is also underlined by epicenter distributions from local seismic networks [Régnier et al., 1992; Smalley et al., 1993], relocated teleseismic events [Engdahl and Villaseñor, 2002], and is in good agreement with the location of the regional active faults (Figures 1c and 1d). Close to the city of San Juan, it has been proposed that the fault responsible for the 1944 San Juan earthquake could be either the west verging thrusts associated with the Eastern AP [Siame et al., 2002; Alvarado and Beck, 2006] or an east verging, deep crustal thrust located beneath the Eastern AP thrust system [Meigs et al., 2006; Meigs and Nabelek, 2010; Rockwell et al., 2014]. Combining the relative locations of the double main shock and its aftershocks with observed coseismic elevation changes, Kadinsky-Cade et al. [1985] concluded that most of the coseismic slip associated with the 1977 Caucete earthquake occurred on a west dipping fault, buried beneath the eastern flank of the SPDP. However, a common characteristic of these two large earthquakes is that only limited surface coseismic ruptures were produced. 


\section{Methods}

In this study, the regional geomorphic characteristics of the SPDP have been investigated at the regional scale using an extract of the 3 arc sec (roughly $90 \mathrm{~m}$ ) resolution digital elevation model (DEM) from the Shuttle Radar Topography Mission (SRTM) database (ftp://e0srp01u.ecs.nasa.gov/srtm/version2/SRTM3/), which has been postprocessed according to Reuter et al. [2007] to remove the no-data regions due to insufficient textural detail, characteristic of mountainous regions such as the Andes (http://srtm.csi.cgiar.org). The topographic grid has been processed in a Geographical Information System (Mapinfo), combined with Rivertools and Vertical Mapper softwares, to derive slope maps or vector objects like stream segments and watershed boundaries. Together with topographic and slope grids, a combination of SPOT panchromatic images and Landsat TM satellite images was used to map the alluvial landforms that skirt the piedmonts of the SPDP. Figure 2a presents a combination of these different geographic layers, with the main watersheds and the alluvial units mapped as a function of their hypsometric integral values and average slopes, respectively. At selected sites (see section 5), topographic surveys were performed with a total station (Leica TC 805), using the reference point 14-059 of the PASMA network (National Geographic Institute of Argentina), and planar coordinates (Gauss Krüger, Zone 2, and WGS84 datum).

To provide chronological constraints on alluvial terraces affected by fault activity and to estimate bounds on the denudation rates associated with the SPDP development, we used in situ-produced ${ }^{10}$ Be concentrations resulting from spallation and muonic reactions on Silicon and Oxygen in quartz minerals. For complete reviews of in situ-produced cosmogenic techniques, one can refer to Gosse and Phillips [2001] and Balco et al. [2008] as well as to the supplemental material associated with this article. Measurements of in situ-produced

${ }^{10} \mathrm{Be}$ concentrations were performed at the French AMS national facility ASTER (CEREGE, Aix-en-Provence) [Arnold et al., 2010]. The in situ-produced ${ }^{10}$ Be results and derived minimum CRE ages and denudation rates are summarized in Table 1.

To examine the statistical significance of the cosmogenic nuclide-derived minimum CRE ages and maximum denudation rates, outliers were first identified applying the reduced chi-square statistic [Ward and Wilson, 1978] and the mean square weighted deviation (MSWD) for each group of samples. This allows accounting for the relative importance of both the internal and external reproducibility and comparing the observed variability defined by the uncertainties of the data [Mclntyre et al., 1966]. To downplay the weight of high or low outliers, another approach consists of applying a nonparametric bootstrap calculation of the central value for a given population of samples and its associated uncertainties. This bootstrap technique is particularly suitable for small data sets and/or when probability distributions are nonnormal [Efron, 1979; Efron and Tibshirani, 1986, 1993; Davison and Hinkley, 1997]. More importantly, it has the particularity of being statistically law independent. The numerical results of the MSWD and bootstrap analyses are presented in the supporting information associated with this article.

\section{The Sierra Pie de Palo Range}

\subsection{Geomorphic Characteristics of the Sierra Pie de Palo Range}

Located in the westernmost SP (Figure 1c), the SPDP is a NNE striking ellipsoid basement block (80 km long and $40 \mathrm{~km}$ wide) that reaches up to $3162 \mathrm{~m}$ elevation at Cerro Mogote (Figure 2a). As described above, it is an actively growing basement anticline [Ramos et al., 2002] associated with a high level of crustal seismicity [Régnier et al., 1992; Smalley et al., 1993], which forms a dissymmetrical arch with steeper slopes along its northern and eastern sides compared to its western and southern sides (Figures 2b and 2c) [Siame et al., 2006]. The western long limb is dissected by two main gorges, superimposed on ENE-WSW basement lineaments (Guayaupa-Lima and Grande El Molle) (Figures 1c and 2a) [Baldis et al., 1979; Instituto Nacional de Prevencòn Sísmica (INPRES), 1982]. However, at least at a first order, neither NNW striking topographic sections nor the eastern front reveal any significant vertical or horizontal displacements associated with these basement structures, which probably remained inactive during Cenozoic times.

The relatively flat areas that comprise most of the SPDP topography define a convincing surface envelope along both N-S and E-W directions (Figures $2 \mathrm{~b}$ and $2 \mathrm{c}$ ). These flat surfaces are characteristic of most of the Pampean ranges and have long been referred to as the "Pampean peneplain" [Jordan et al., 1989]. This erosion surface is probably polygenic, and its age is still a matter of debate, with stratigraphic data indicating that it may have formed after Middle Paleozoic to Cretaceous [e.g., Jordan et al., 1989; Carignano et al., 1999]. According to Jordan et al. [1989], this regional erosion surface has been deformed and exhumed during the 


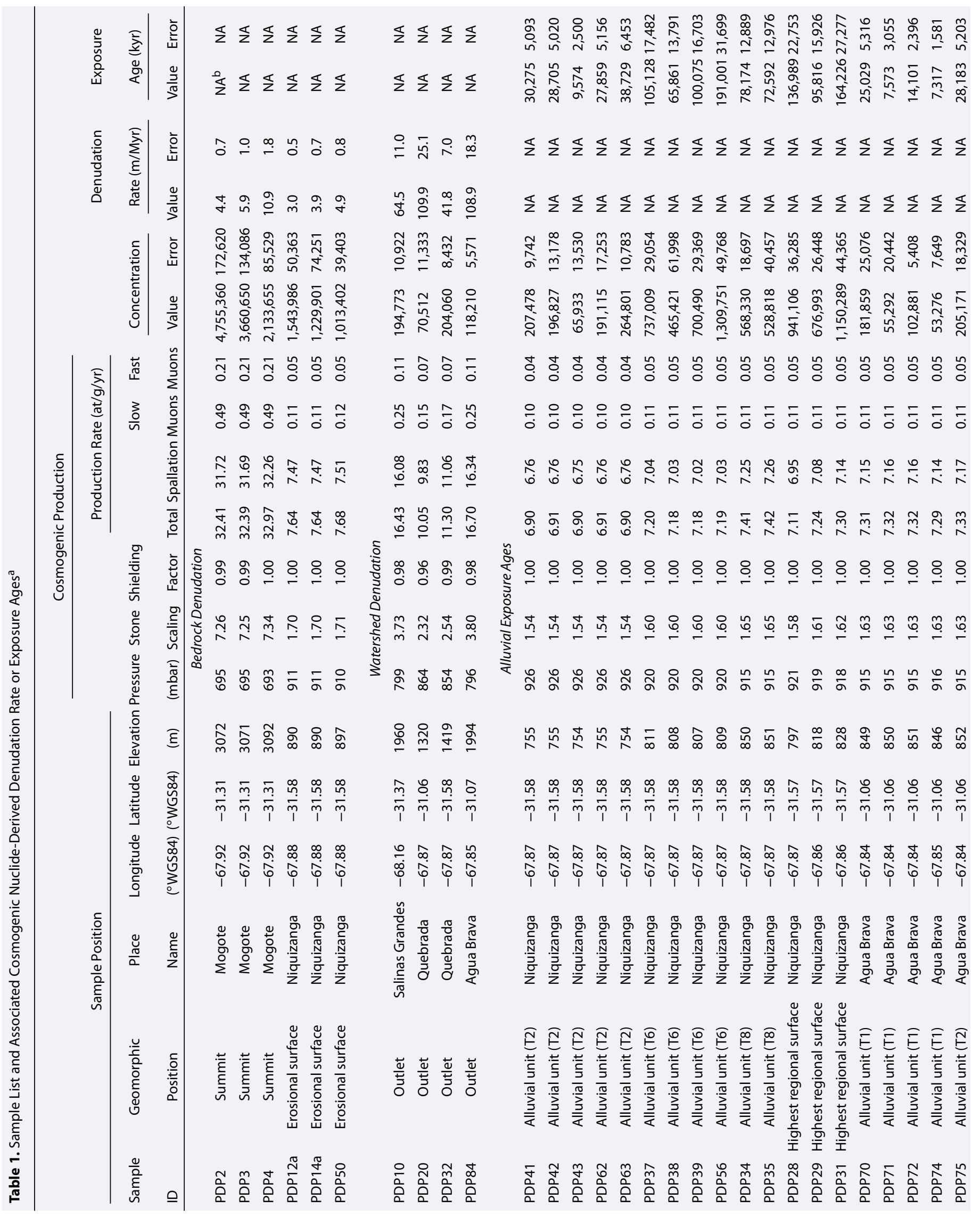




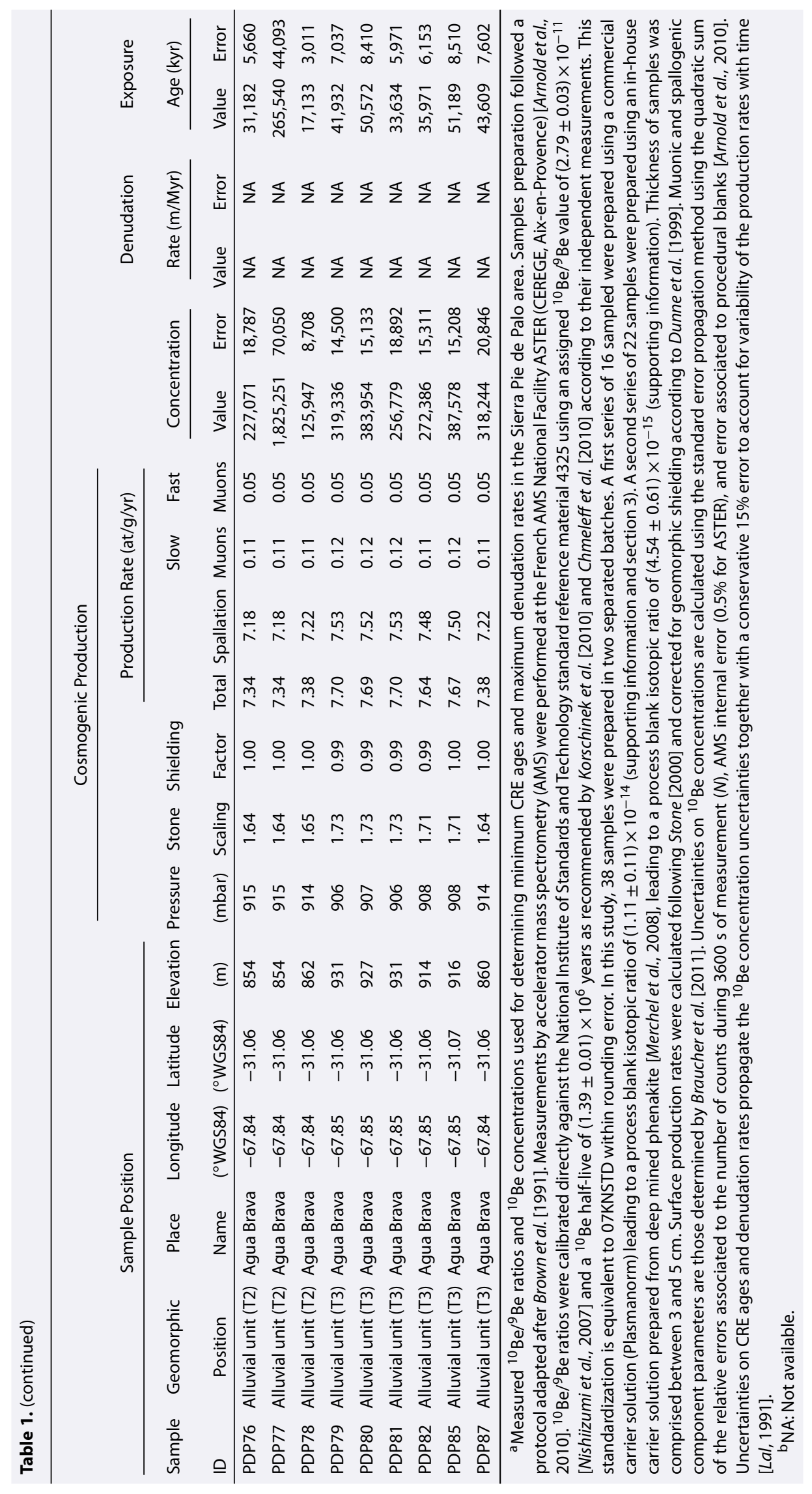


Neogene. Conversely, Carignano et al. [1999], Rabassa et al. [2010], Löbens et al. [2011, 2013a, 2013b], Bense et al. [2013], and Enkelmann et al. [2014] considered that Pampean reliefs may have persisted since the Mesozoic. Nowadays, the SPDP is only constituted by Paleozoic and Precambrian basement rocks, without any younger outcropping geological formations [Ramos and Vujovich, 2000]. East of the Bermejo Valley, at the same latitude as the SPDP, the southern tip of Sierra de la Huerta is partly covered by Triassic deposits that are affected by Quaternary deformation along the Las Chacras Fault [Costa et al., 2000; Siame et al., 2005] (Figure 1c). To the south, the SPDP is covered by the Late Quaternary sand dunes field of Medanos Grandes [Tripaldi et al., 2010]. To the east and northeast of the SPDP, Pliocene deposits including materials derived from the AP suggest that the SPDP was once covered by Andean foreland deposits before being exhumed during the regional Neogene deformation [Ramos and Vujovich, 2000; Ramos et al., 2002]. Whether the regional erosion surface formed during one or several denudation cycles is beyond the scope of this paper. However, it is an important regional geomorphic marker that allows gauging the deformation that has affected the SPDP.

The lithological characteristics and semiarid climate contributed to good preservation of the surface envelope of the basement fold. Consequently, considering that these conditions are fairly constant throughout the range, any tectonic perturbation should be discriminated using geomorphic indices associated with the drainage network. Among such indices, the hypsometric integral value, which is related to the degree to which a landscape is dissected, is commonly used to discriminate between tectonically active against inactive areas [Strahler, 1952]. This morphometric approach shows that the watersheds with higher integral hypsometric values are preferentially located along the northern and eastern flanks of the SPDP (Figure 2a). The elongated, almost rectilinear shape of the watersheds that dissect the northern and eastern flanks also correlate well with the steep slopes in these areas. Another line of geomorphic evidence for tectonic activity is the distribution pattern of the alluvial terraces that skirt the mountain periphery, with more alluvial generations along the northern and eastern flanks than at the toe of both the western and southern flanks. Furthermore, the average slope of these alluvial units increases up to $8-11^{\circ}$ along the northeastern corner of the range, whereas it is elsewhere restricted to less than $4^{\circ}$, close to the original depositional slope (Figure 2a). All together, these geomorphic observations strongly suggest that most of the Quaternary deformation associated with this basement fold is concentrated along its northern and eastern flanks [Siame et al., 2006].

To reconstruct the surface envelope of the SPDP, the ridges and local summits have been extracted from the SRTM DEM together with the areas where the local slope is lower than $10^{\circ}$ (Figures $2 \mathrm{~d}$ and $2 \mathrm{e}$ ). This resulted in a database of elevation points that was then interpolated (Inverse Distance Weighting) to produce a theoretical surface envelope that can be considered as a relatively good proxy for the shape of the SPDP fold (Figure 2f). The difference between this theoretical envelope and the present-day topography represents the minimum volume of rocks that has been eroded by fluvial and hillslope processes since the SPDP has been uplifted. In Figure $2 \mathrm{~g}$, the present-day vertical incision is shown in map view and unveils total vertical incision as high as $700 \mathrm{~m}$ for the main valleys. The spatial integration of these vertical incision heights allows estimating a total eroded volume of about $135 \mathrm{~km}^{3}$.

\subsection{Structural Model for the Sierra Pie de Palo Range}

The SPDP is bounded by three regional tectonic structures (Figure 3). The major structure controlling the eastern border of the SPDP is a matter of debate. One possibility is the Ampacama-Nikizanga Fault, which runs for roughly $65 \mathrm{~km}$ with an average strike of $\mathrm{N} 21^{\circ} \mathrm{E}$, and has been described as an east dipping fault that splays at about $20 \mathrm{~km}$ depth off a midcrustal décollement in connection with the west verging, thick-skinned master fault bordering the Sierra de la Huerta, south of the Sierra Valle Fértil System [Langer and Bollinger, 1988; Costa et al., 2000; Ramos et al., 2002]. However, leveling surveys including after the 1977 Caucete earthquake [Kadinsky-Cade et al., 1985; Reilinger and Kadinsky-Cade, 1985] as well as crustal reconstructions from shallow and deep seismic profiles [Zapata, 1998] favor a west dipping, east verging blind fault below the eastern border of the SPDP (Figure 3). This hypothesis is in good agreement with the observed first-order topographic signature of a steeper eastern flank and with the fact that, along most of the eastern flank length, the Neogene strata generally dip to the east and the Plio-Quaternary deposits are not affected by any major fault (Figure 4). To avoid any confusion with the previously described Ampacama-Niquizanga Fault, we refer to this crustal, antithetic thrust as the Eastern Pie de Palo Fault (EPF).

The northern boundary of the range is delimited by the North Pie de Palo Fault (NPF), a roughly E-W transpressive, left-lateral fault that extends over $80 \mathrm{~km}$ from the Matagusanos basin, south of the Mogna Anticline in the Eastern Precordillera [Zapata, 1998], to the Sierra de Valle Fértil Fault (Figure 3). This regional structure 


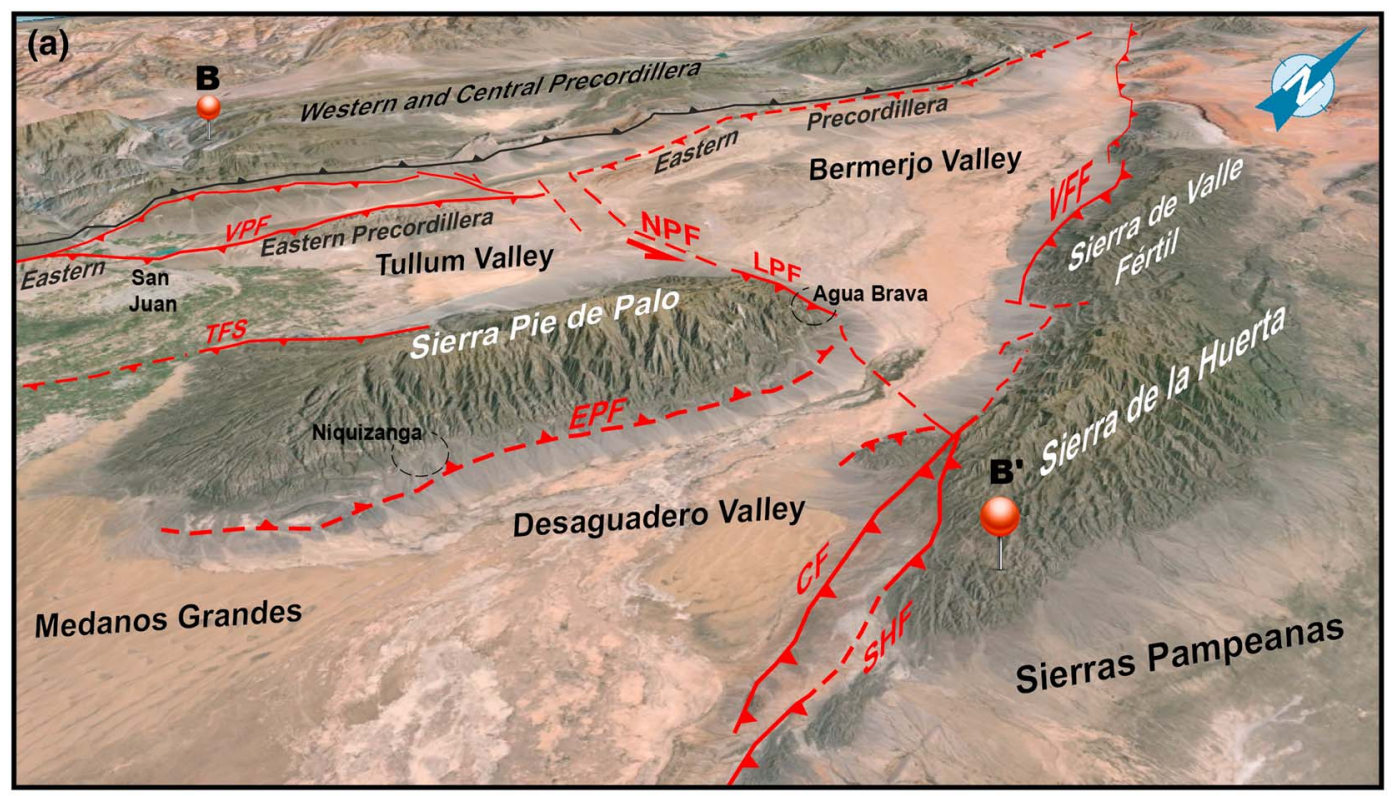

(b)

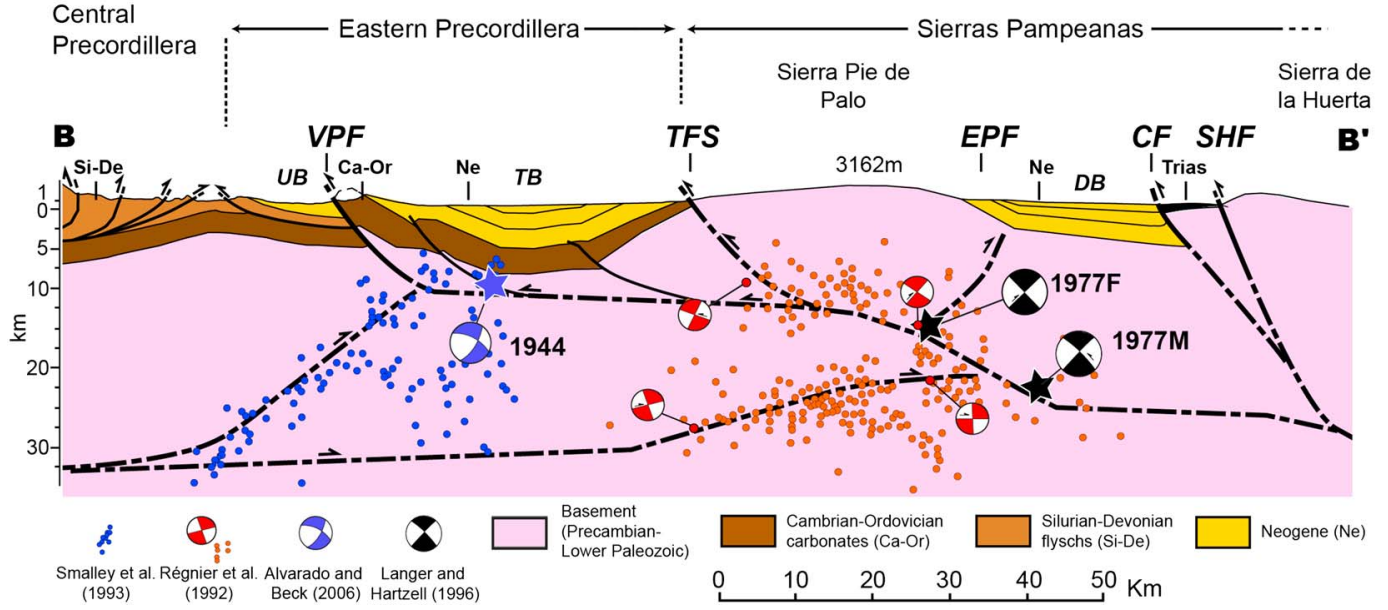

Figure 3. Tentative structural model for the Sierra Pie de Palo. (a) Schematic structural map showing the major faults in vicinity of the SPDP. Same fault abbreviations than in Figure 1. (b) Schematic cross section (B- $\left.\mathrm{B}^{\prime}\right)$ at about $31.5^{\circ} \mathrm{S}$ latitude showing the thick-skinned deformation front (modified after Vergés et al. [2007]); Central Precordillera after Von Gosen [1992]; Eastern Precordillera after Zapata [1998], Siame et al. [2002], and Alvarado and Beck [2006]; and structure at depth modified after Régnier et al. [1992], Smalley et al. [1993], and Ramos et al. [2002].

coincides with a major northward change in the basement depth across the southern boundary of the Bermejo basin [Jordan and Allmendinger, 1986]. The NPF runs along the northern edge of the SPDP for approximately $26 \mathrm{~km}$ at the contact between the metamorphic basement and the Neogene foreland strata. This part of the NPF, referred as the Pajaritos Fault [Costa et al., 2000], has a rectilinear trace, suggesting a relatively high dip to the south (at least $50-60^{\circ}$ ). At the northeastern corner of the SPDP, the Pajaritos Fault affects a series of alluvial landforms and exhibits a well-developed, $4 \mathrm{~km}$ long, north facing fault escarpment with a right-stepping relay that agrees well with a horizontal left-lateral component (Figure 5).

Finally, the southern half of the western SPDP side is bounded by the Tullum Fault System (TFS) [Zambrano and Suvires, 2008], which extends over $120 \mathrm{~km}$ farther south (Figures 1c and 3). This fault system is described as superimposed on the suture between the Cuyania and Precordillera terranes [Ramos et al., 2002] and shows to the south of the SPDP limited and isolated bedrock (e.g., Cerro Salinas) exposures along strike (Figure 1c). Considering that the western border of the SPDP is relatively linear only along its southwestern termination and 

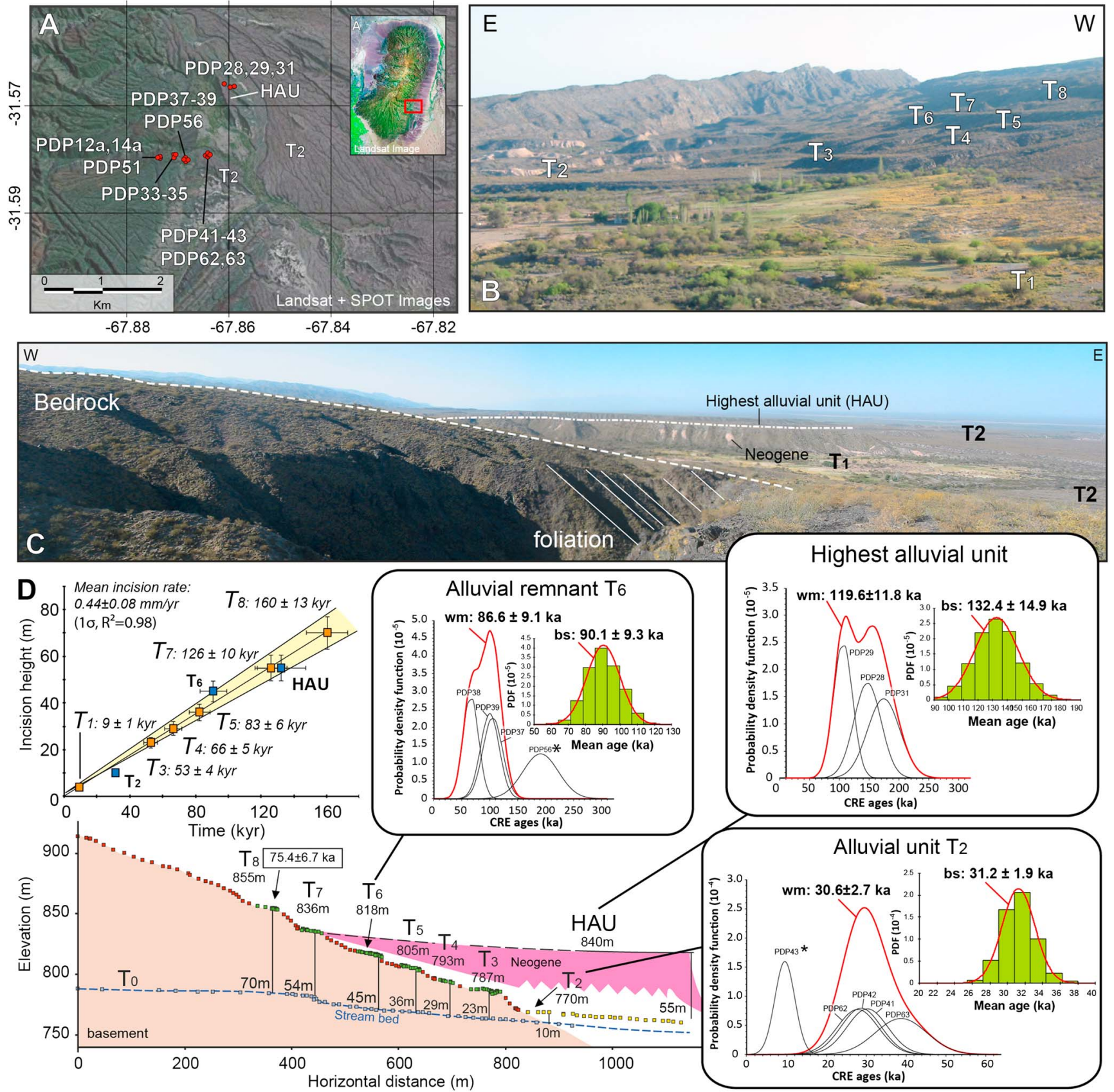

Figure 4. Niquizanga area (southeastern SPDP). (a) Sample location map overlain on a combination of SPOT and Landsat images. (b) Field photograph toward the southwest showing the alluvial remnants stepped onto the SPDP lowermost topography. Alluvial units are labeled from $\mathrm{T}_{0}$ corresponding to the present-day streambeds. (c) Panoramic photograph showing the dipping paleoerosion surface and its lateral relationships with the highest alluvial unit (HAU). (d) Topographic cross section constructed across the stepped alluvial remnants from field topographic survey. The HAU's elevation is projected onto the cross section for correlation. Numbers give the local river incision measured vertically below the alluvial remnants to the present-day streambed. Statistical analysis of CRE ages obtained for the alluvial units $\left(T_{2}, T_{6}\right.$, and $\mathrm{HAU}$ ). For each group of samples, outliers are identified $\left(^{*}\right)$; weighted mean (wm) and bootstrap mean (bs) are shown in the form of probability function plots (see also supporting information and section 3). Local incision rate derived from vertical incision measurements and CRE dating of the $\mathrm{T}_{2}, \mathrm{~T}_{6}$, and $\mathrm{HAU}$ (solid blue squares). Assuming constant incision rate allows estimating the age bracketing (italic numbers) of the other alluvial units (solid orange squares). 

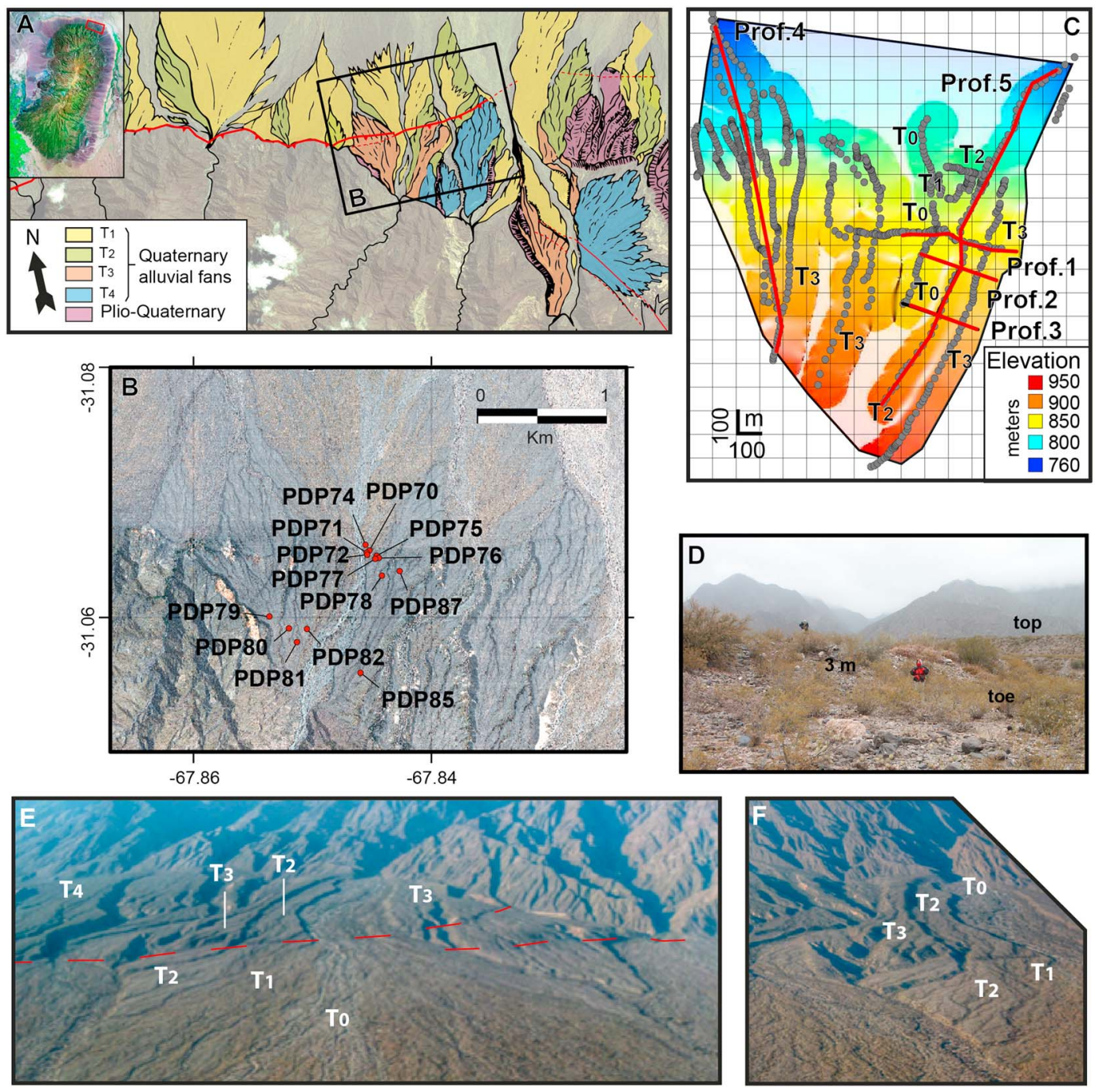

Figure 5. Agua Brava area (northern SPDP). (a) Geomorphic map of the Los Pajaritos Fault along the northern border of the SPDP showing the distribution of the alluvial units overlaid on to a Quickbird satellite image. Alluvial units are labeled from $\mathrm{T}_{0}$ corresponding to the present-day streambed. Inset shows the location of Figure 5a. (b) Sample location map overlain on an extract of the Quickbird image. (c) Map view of the data acquired during the topographic survey (solid grey circles) locating the topographic profiles (thick red lines). The topographic profiles are depicted in Figure 6. (e) Field photograph of the $3 \mathrm{~m}$ high topographic escarpment affecting the younger $\mathrm{T}_{1}$ alluvial unit. (Figures $5 \mathrm{e}$ and $5 \mathrm{f}$ ) Bird's eye view photographs taken from a plane during a reconnaissance survey showing the different alluvial units and the topographic escarpment associated with the Pajaritos Fault.

the first-order topographic signature in both E-W and N-S directions, the TFS is likely to have been reactivated to accommodate the propagation of the SPDP toward the south.

To account for the geomorphic and topographic signatures presented in this paper and previously published geophysical interpretations [Volponi et al., 1983; Kadinsky-Cade et al., 1985; Reilinger and Kadinsky-Cade, 1985; Zapata, 1998], we consider that the development of the SPDP basement anticline should have been mainly controlled by (1) a blind, antithetic, east verging thrust fault located at depth below the eastern basement fold forelimb (EPF) and (2) a reverse, left-lateral crustal ramp (Pajaritos Fault) running along the northern border of the SPDP, which prevented its northward propagation.

\section{Uplift and Denudation Rates}

In the following sections, the morphotectonic settings of the sites selected for quantifying Quaternary rates of vertical incision and surface uplift are presented together with the obtained minimum CRE ages. The first 
series of alluvial terraces is located along the southeastern border of the SPDP (Niquizanga) and allows deciphering rates of river incision and basement uplift associated with the growth of the fold above the buried EPF. The second series of alluvial terraces is located at the northeastern corner of the SPDP (Agua Brava) and allows estimating uplift rates associated with the eastern segment of the NPF (Pajaritos Fault). Finally, the selected sites for quantifying denudation rates associated with the growth of the SPDP basement anticline are presented together with the cosmogenic nuclide-derived denudation rates, allowing discussion of the influence of denudation processes on inferred tectonic rates.

\subsection{Rates of Vertical Incision and Surface Uplift (SE Flank of SPDP, Niquizanga)}

At Niquizanga (Figure 4), the Neogene strata plunge roughly $15-20^{\circ}$ toward the east at the toe of the mountain range, in conformity with the plunge of the erosion surface cutting the basement rocks. Upward and eastward, the Neogene strata plunge diminishes, leaving only a slight angular unconformity with the overlying Quaternary alluvial deposits that skirt the mountain piedmont. This alluvial material derived from the SPDP form thin $(<3-5 \mathrm{~m}$ ) sedimentary deposits that overly the Neogene foreland strata exposed within incised cuts of the streambeds and can be arranged into two distinctive groups. The first group consists of alluvial terraces, labeled $T_{1}$ and $T_{2}$ with respect to the present-day streambeds $\left(T_{0}\right)$, and a high alluvial unit, labeled $\mathrm{HAU}$ in Figure 4. Alluvial terraces $\mathrm{T}_{1}$ and $\mathrm{T}_{2}$ merge downstream with the bajada to the east of the mountain front. While alluvial terraces $T_{1}$ and $T_{2}$ generally stand less than several meters above $T_{0}$, the HAU rises more than $50 \mathrm{~m}$ above the present-day streambeds (Figure 4). The alluvial terrace $T_{2}$ extends widely and exhibits relatively well-preserved, large boulders and subdued surface features like bars and swales. The second group consists of stepped, thin $(<1 \mathrm{~m})$ veneers of proximal alluvial material that have been abandoned and partly notched onto the slope of the mountain range (Figure 4). These alluvial remnants have been labeled upward from $T_{3}$ to $T_{8}$ with respect to the present-day streambed. From $T_{3}$ to the $H A U$, the surface morphologies consist of deflated stony desert pavements with rare boulders, relatively more frequent cobbles, and well-developed dark rock varnish. Actually, besides the higher degree of dissection characterizing the HAU with respect to the regional $\mathrm{T}_{2}$, nothing much is left on these surfaces to help distinguish them except their respective topographic position relative to the present-day streambeds. Another important observation is that the HAU apparently connects laterally to the mountain range, making it a probable equivalent of the preserved alluvial remnant $\mathrm{T}_{7}$ (Figure 4).

To precisely define the chronological framework of this series of alluvial units, we measured the cosmogenic in situ-produced ${ }^{10} \mathrm{Be}$ concentrations within boulders and cobbles sampled from the surface of the alluvial $T_{2}$ and the $\mathrm{HAU}$, as well as from the alluvial remnants $\mathrm{T}_{6}$ and $\mathrm{T}_{8}$. From the alluvial terrace $\mathrm{T}_{2}$, four quartzite boulders (PDP41, PDP42, PDP62, and PDP63) and one quartz vein cobble (PDP43) were analyzed (Table 1). Except for the smallest quartz vein cobble, which shows a significantly younger minimum CRE age, all the analyzed boulders agree with an abandonment at roughly $30 \mathrm{ka}$ (Table 1). For these four samples, the weighted mean is $31 \pm 3 \mathrm{ka}$ (Figure 4). Even if it cannot be strictly discarded from a statistical point of view, the boulder PDP63 is slightly older, maybe due to some ${ }^{10} \mathrm{Be}$ content inherited from previous exposure(s) before its deposition. Excluding PDP43 from the data set (low outlier), and bootstrapping the other CRE ages allows tuning down the contribution of sample PDP63, yielding a mean value of $31 \pm 2 \mathrm{ka}$ (Figure 4). From the HAU, two quartz vein boulders (PDP28 and PDP29) and one quartz vein cobble (PDP31) were analyzed and all agree on a weighted mean value of $120 \pm 12 \mathrm{ka}$ (Figure 4). Within these three samples, PDP29 seems slightly younger than the others even if it cannot be excluded from a statistical point of view. Bootstrapping this data population allows tuning down its contribution, yielding a mean value of $132 \pm 15 \mathrm{ka}$ (Figure 4). From the alluvial remnant $\mathrm{T}_{6}$, we analyzed two quartz vein boulders (PDP37 and PDP38), one granitoid boulder (PDP39), and one quartz vein cobble (PDP56). This last sample exhibits a significantly higher minimum CRE age of $191 \pm 32 \mathrm{ka}$, probably due to some ${ }^{10} \mathrm{Be}$ content inherited from previous exposure(s) before its deposition, whereas the other three samples agree on a abandonment age at roughly $90 \mathrm{ka}$, with a weighted mean of $87 \pm 9 \mathrm{ka}$ and a booststrap mean of $90 \pm 10 \mathrm{ka}$ (Figure 4). From the alluvial terrace $T_{8}$, two quartz vein boulders (PDP34 and PDP35) exhibit consistent minimum CRE ages of $78 \pm 13$ and $73 \pm 13 \mathrm{ka}$, respectively (Table 1).

The CRE ages obtained for these different alluvial terraces are relatively consistent and increase with the topographic position of the terraces above the streambed, with the exception of the alluvial remnant $\mathrm{T}_{8}$. Considering the bootstrapped central values of our groups of minimum CRE ages, the alluvial terrace $T_{2}$ was abandoned at $31 \pm 2 \mathrm{ka}$, while the $\mathrm{HAU}$ and the alluvial remnant $\mathrm{T}_{6}$ were abandoned at $133 \pm 15 \mathrm{ka}$ and $90 \pm 10$ ka, respectively. The younger CRE age derived from the alluvial remnant $T_{8}$ compared to that of $T_{6}$ is 
not surprising. This highest alluvial remnant is poorly preserved with rare boulders and cobbles and has probably been reworked by postabandonment processes and/or contaminated by cobbles and boulders derived from the surrounding bedrock. Indeed, if the correlation of the $\mathrm{HAU}$ with $\mathrm{T}_{7}$ is correct, then $\mathrm{T}_{8}$ should be older than $133 \mathrm{ka}$.

At the outlet of Quebrada Niquizanga, we performed a detailed topographic survey to determine the amount of vertical incision with respect to the present-day streambed (Figure 4). From this data set, the present-day streambed is incised $10 \mathrm{~m}$ and $45 \mathrm{~m}$ below $\mathrm{T}_{2}$ and $\mathrm{T}_{6}$, respectively. Considering that $\mathrm{T}_{2}$ and $\mathrm{T}_{6}$ were abandoned at $31 \pm 2 \mathrm{ka}$ and $90 \pm 10 \mathrm{ka}$, respectively, these incision values imply rates of $0.3 \pm 0.2 \mathrm{~mm} / \mathrm{yr}$ and $0.5 \pm 0.1 \mathrm{~mm} / \mathrm{yr}$ (Figure 4). The HAU is hanging roughly $50 \mathrm{~m}$ above the present-day streambed, which implies an incision rate of $0.4 \pm 0.1 \mathrm{~mm} / \mathrm{yr}$ since it was abandoned at $133 \pm 15 \mathrm{ka}$ (Figure 4). All together, these estimates agree within their uncertainties, suggesting a fairly constant incision rate through time, with a mean value of $0.4 \pm 0.1 \mathrm{~mm} / \mathrm{yr}\left(R^{2}=0.95\right)$ (Figure 4). Assuming such a constant incision rate allows us to establish a tentative chronological framework for the abandonment of the levels identified as $T_{3}, T_{4}, T_{5}, T_{7}$, and $T_{8}$ at $53 \pm 4,66 \pm 5,83 \pm 6,126 \pm 10$, and $160 \pm 13 \mathrm{ka}$, respectively (Figure 4). The $35 \mathrm{~m}$ elevation difference between the surfaces of $T_{2}$ and $T_{6}$ can be regarded as a proxy for surface uplift during the time span between their respective abandonments, which is over $60 \pm 7 \mathrm{ka}$. These elevation and time differences lead to a surface uplift rate of $0.6 \pm 0.1 \mathrm{~mm} / \mathrm{yr}$.

In summary, along the southeastern border of the SPDP, the landscape evolution seems to be a direct response to the progressive exhumation of the basement above the buried EPF fault, with an incision of the stream networks at a relatively constant rate of $0.4 \pm 0.1 \mathrm{~mm} / \mathrm{yr}$. Even if the precise geometry of the EPF is still speculative at depth, the projection of a minimum incision rate of $0.3 \mathrm{~mm} / \mathrm{yr}$ on a reverse fault plane dipping between 45 and $60^{\circ}$ suggests a minimum fault slip rate of $0.4-0.6 \mathrm{~mm} / \mathrm{yr}$, which is a lower bound because fluvial incision might not have reached equilibrium. The upper bound of the incision rate, together with the $0.6 \pm 0.1 \mathrm{~mm} / \mathrm{yr}$ surface uplift rate determined from the differential elevation between $T_{2}$ and $T_{6}$, suggest the possibility for higher fault slip rates of $0.4-1.2 \mathrm{~mm} / \mathrm{yr}$.

\subsection{Rates of Vertical Incision and Surface Uplift (Northern Flank of SPDP, Agua Brava)}

At Agua Brava, along the northeastern corner of the SPDP (Figures 5 and 6), the alluvial materials form thin $(<3 \mathrm{~m})$ sedimentary deposits that skirt the mountain piedmont, unconformably overlying the Neogene foreland strata exposed in incised banks along the stream network. These alluvial terraces can be arranged into four generations based on their topographic positions with respect to present-day streambeds $\left(T_{0}\right)$ and are labeled, from younger to older, $T_{1}$ to $T_{4}$ (Figure 5). First, the dissection degree of the different alluvial units increases with their relative topographic positions (Figure 5 ). Alluvial terrace $T_{1}$ has a well-preserved surface morphology with bars and swales formed by abraded boulders and subangular cobbles and obvious rill-wash features. Relative to the topographic positions, the other alluvial terraces are characterized by diminishing preservation of streambed features together with increasing development of desert pavement and dark rock varnish as well as lack of large boulders. Among the alluvial generations that skirt the piedmont, the three younger ones $\left(T_{1}, T_{2}\right.$, and $\left.T_{3}\right)$ are clearly affected by fault activity, showing increasing escarpment heights with relative age of the alluvial terraces (Figure 6).

To constrain the chronology of the terrace abandonment, we sampled well-preserved cobbles and boulders from atop the alluvial terraces $T_{1}, T_{2}$, and $T_{3}$ (Figure 5), avoiding areas close to terrace risers or incised gullies. Regarding alluvial terrace $T_{3}$, we sampled the best preserved upstream part of the surface to prevent any complication due to postabandonment processes (Figure 5). The sampling was also performed on both sides of the mainstream to verify isochronicity of the surface (Figure 5). The sample population comprises two boulders of dark quartzite (PDP79 and PDP81), one cobble of quartzite (PDP87), one quartz vein cobble (PDP85), and one amalgam of quartz vein pebbles (PDP80). Within their uncertainties, all the samples delivered consistent minimum CRE ages and yield a weighted mean age of $41 \pm 3 \mathrm{ka}$. Among these samples, the quartz vein cobble and the amalgam of quartz vein pebbles lead to minimum CRE ages that seem slightly older than the rest of the population (Table 1). For this group of samples, the bootstrap calculation of the mean value yields $43 \pm 3 \mathrm{ka}$ for the $\mathrm{T}_{3}$ terrace (Figure 6).

On top of terrace $T_{2}$, we sampled one gneiss boulder (PDP75), two quartzite boulders (PDP76 and PDP78), and one quartz vein cobble (PDP77). Both minimum CRE ages determined for PDP75 and PDP76 agree within their uncertainties, their mean value being $30 \pm 4 \mathrm{ka}$. The quartz vein cobble yielded a much older minimum CRE age of $266 \pm 44 \mathrm{ka}$. Conversely, one of the quartzite boulders (PDP78) delivered a much younger minimum 

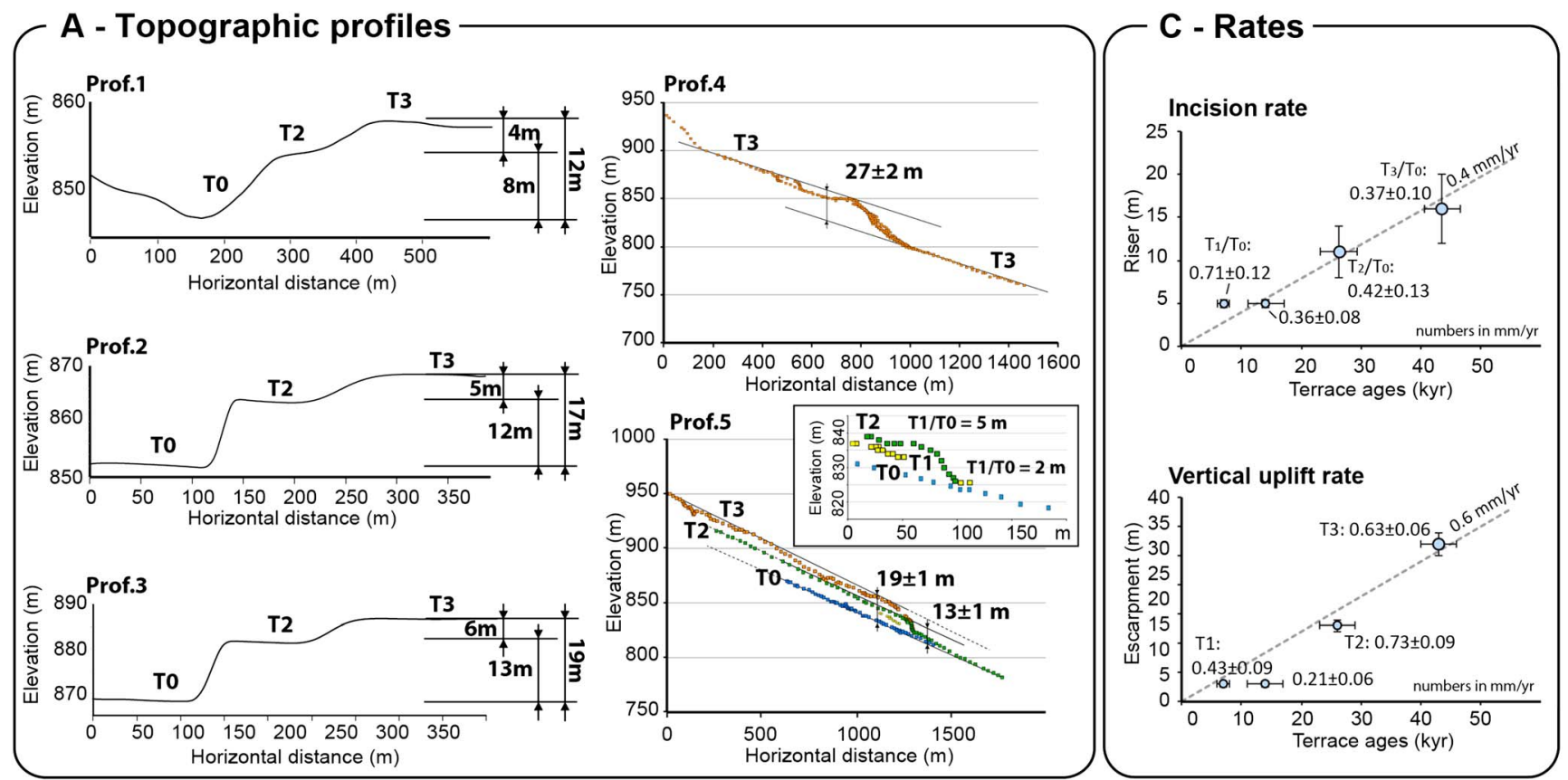

\section{B - Minimum CRE ages}

Alluvial surface $\mathrm{T3}$

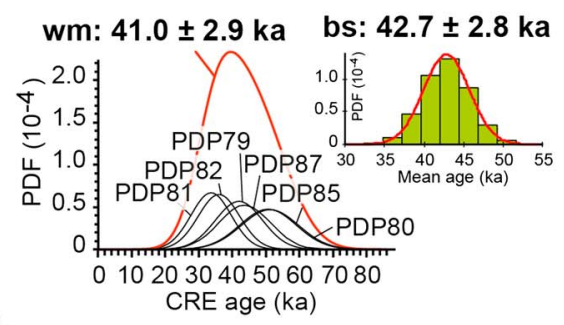

Alluvial surface T2

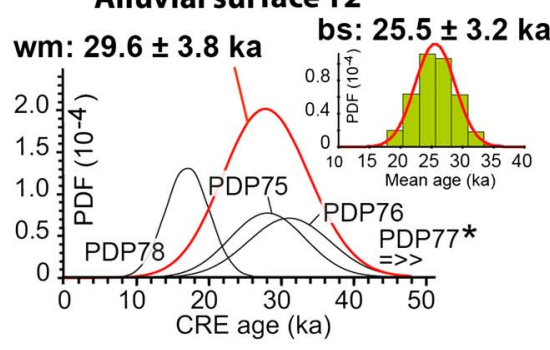

Alluvial surface T1

bs: $13.5 \pm 2.8 \mathrm{ka}$

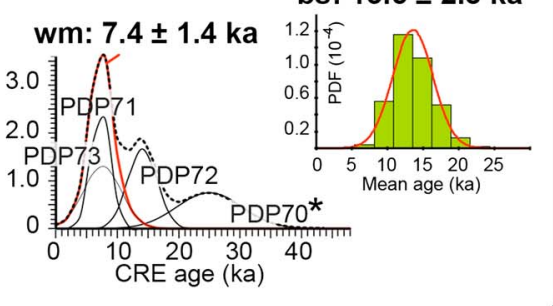

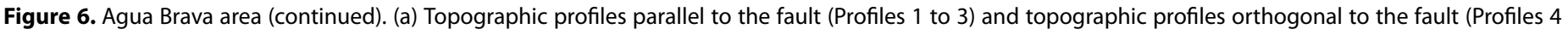

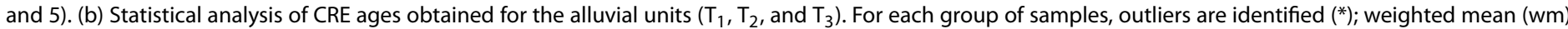

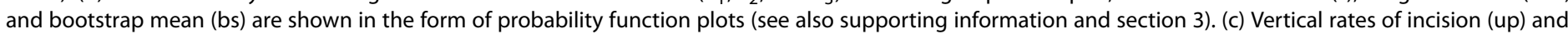
surface uplift (down) derived from the combination of surface dating and topographic survey.

CRE age of $17 \pm 3 \mathrm{ka}$. The most obvious interpretation regarding the quartz vein cobble PDP77 is that it bears a significant amount of cosmogenic ${ }^{10} \mathrm{Be}$ acquired during previous exposure(s) before its deposition on alluvial $\mathrm{T}_{2}$. Regarding PDP78, no clear evidence for postabandonment disturbance was noted in the field. The young age might thus result either from unrecognized postabandonment processes or overbank flooding during Late Glacial Maximum. Without further constraints, we bootstrapped the data population, excluding PDP77, to estimate a conservative mean value of $26 \pm 3$ ka for terrace $T_{2}$ abandonment (Figure 6).

On top of terrace $T_{1}$, we sampled one gneiss boulder (PDP71) and three granitoid boulders (PDP70, PDP72, and PDP74). Two samples (PDP71 and PDP74) agree with a CRE age of $7 \pm 1 \mathrm{ka}$, whereas the other two samples are significantly older, yielding minimum CRE ages of $25 \pm 5 \mathrm{ka}$ (PDP70) and $14 \pm 2 \mathrm{ka}$ (PDP72). One sample (PDP74) was taken on the surface downstream from the topographic escarpment, whereas the other three samples were taken from above it. Thus, one cannot argue that the youngest CRE ages are due to boulders previously shielded and reworked from the degradation of the topographic escarpment. One possible interpretation is that the two older boulders are reworked from alluvial materials cannibalized by the alluvium capping alluvial $T_{1}$ during its deposition. Indeed, the minimum CRE ages associated with the samples PDP70 and PDP72 are close to those of the samples measured on $T_{2}$ top. Given the observed dispersion of the minimum CRE ages, we considered that abandonment age for the alluvial $\mathrm{T}_{1}$ can be bracketed between a lower 
bound given by the youngest CRE ages ( $7 \pm 1 \mathrm{ka}$ ) and an upper bound given by the bootstrapped central value of the whole data population ( $14 \pm 3 \mathrm{ka})$, which is between 6 and $17 \mathrm{ka}$.

Using the topographic data acquired in the field (Figure 5), we determined incision values of the present-day streambed along three profiles that are located $150 \mathrm{~m}$ (Figure 6, profile 1), $300 \mathrm{~m}$ (Figure 6, profile 2), and $500 \mathrm{~m}$ (Figure 6, profile 3) upstream of the topographic escarpment. The vertical incision of $\mathrm{T}_{0}$ with respect to alluvial terraces $T_{3}$ and $T_{2}$ increases upstream from 12 to $19 \mathrm{~m}$ and from 8 to $13 \mathrm{~m}$, respectively (Figure 6). Integrated over the last $43 \pm 3 \mathrm{ka}$ and $26 \pm 3 \mathrm{ka}$, these measurements yield vertical incision rates of $0.4 \pm 0.1 \mathrm{~mm} / \mathrm{yr}$, which are similar to those determined at Niquizanga. Upstream of the topographic escarpment, the alluvial terrace $T_{1}$ is roughly $5 \mathrm{~m}$ above the present-day streambed (Figure 6). Considering the fairly large bracketing of terrace $T_{1}$ abandonment (6-17 ka), this height implies an incision rate ranging from 0.3 to $0.8 \mathrm{~mm} / \mathrm{yr}$.

To determine the topographic height of the escarpment affecting the alluvial terraces $T_{3}$ and $T_{2}$, we extracted long profiles from the topographic data acquired in the field (Figure 5). The profile for terrace $T_{3}$ crosses well-preserved remnants on both the footwall and the hanging wall and indicates a vertical offset of $27 \pm 2 \mathrm{~m}$ (Figure 6, profile 4). The profile for terrace $T_{2}$ indicates a vertical offset of $13 \pm 1 \mathrm{~m}$ (Figure 6, profile 5). Along the same profile, the escarpment for $\mathrm{T}_{3}$ is smaller $(19 \pm 1 \mathrm{~m})$ than that measured on profile 4 . However, given that (1) the topographic escarpment tends to diminish toward the eastern tip of the fault, and (2) terrace $\mathrm{T}_{3}$ is covered and probably partially eroded by terrace $T_{2}$ downstream of the escarpment, this lower height is consistent with that determined using the profile to the west. When combined with the CRE abandonment ages discussed above, the topographic heights determined for $T_{2}$ and $T_{3}$ lead to surface uplift rates of $0.5 \pm 0.1$ and $0.6 \pm 0.1 \mathrm{~mm} / \mathrm{yr}$, respectively (Figure 6). The alluvial surface $T_{1}$ is offset $3 \mathrm{~m}$ by the Pajaritos Fault (Figure 6). Considering the fairly large bracketing of terrace $T_{1}$ abandonment (6-17 ka), this height implies a surface uplift rate ranging from approximately 0.2 to $0.5 \mathrm{~mm} / \mathrm{yr}$.

In summary, local uplift rates estimated from the escarpment heights are similar for terraces $T_{2}$ and $T_{3}$ (over the last 23-46 ka), while the rate seems slightly slower for terrace $T_{1}$ (over the last 6-17 ka). This discrepancy might result from an incomplete upward propagation of coseismic surface ruptures through the very coarse torrential material, which is mainly made of boulders, and/or an insufficiently long time window with respect to the seismic cycle, particularly if a mid-Holocene age is considered. This latter possibility is also suggested by the absence of an obvious knickpoint affecting the streambed profile. Both possibilities may result in a surface displacement deficit for terrace $T_{1}$. Finally, assuming a simple pure reverse movement on the Pajaritos Fault dipping at $\left(50-60^{\circ}\right)$, a minimum slip rate of $1.0 \pm 0.4 \mathrm{~mm} / \mathrm{yr}$ can be calculated over the last 23 to $46 \mathrm{ka}$ and of $0.6 \pm 0.4 \mathrm{~mm} / \mathrm{yr}$ for the period postdating terrace $\mathrm{T}_{1}$ abandonment (6-17 ka).

\subsection{Denudation Rates}

To determine denudation rates, we sampled bedrock outcrops located close to the SPDP summit (Cerro Mogote, $3162 \mathrm{~m}$ ) and along the southeastern border of the range at Niquizanga (Figure 7). The samples comprise quartzite, gneiss, and quartz veins that correspond to the erosional envelope of the fold. The only exception is sample PDP3, which consisted of an amalgam of quartz vein pebbles scattered around the sampling site of PDP2. The measured ${ }^{10}$ Be concentrations of samples PDP2, PDP3, and PDP4 samples correspond to maximum denudation rates of $4 \pm 1,6 \pm 1$, and $11 \pm 2 \mathrm{~m} / \mathrm{Ma}$, respectively (Table 1 ). At Niquizanga, the bedrock samples (PDP12a, PDP14a, and PDP50) yielded similar maximum denudation rates ranging from $3.0 \pm 0.5$ to $5 \pm 1 \mathrm{~m} / \mathrm{Ma}$. The MSWD analysis identified sample PDP4 as a high outlier with respect to the other bedrock samples (Figure 7). This sample was taken from a patch of bedrock hardly outcropping at the surface, close to the antenna of the meteorological station of Mogote, and may have been affected by more locally active surface processes. With the exception of PDP4, all the bedrock samples converge toward maximum bedrock denudation rates of 4-5 m/Ma. Bootstrapping all the data but PDP4 also yields a central value of $4.5 \pm 0.4 \mathrm{~m} / \mathrm{Ma}$ (Figure 7 ), which can be regarded as a conservative estimate of maximum denudation rates affecting the bedrock in the area of the SPDP.

To determine spatially integrated denudation rates, we sampled modern river-borne sediments at the outlets of four watersheds draining the SPDP. Sample PDP10 corresponds to the Quebrada Salinas Grandes watershed, the largest one draining the SPDP to the west, which developed within the Grande El Molle fault zone (Figure 1). Along the northern border, we sampled two watersheds in the area of Agua Brava (PDP20 and PDP84). Along the southeastern border, we sampled the outlet of the quebrada draining the SPDP at Niquizanga (PDP32). The catchment-wide denudation rates are $65 \pm 11 \mathrm{~m} / \mathrm{Ma}$ (PDP10), $42 \pm 7 \mathrm{~m} / \mathrm{Ma}$ (PDP32), $110 \pm 25 \mathrm{~m} / \mathrm{Ma}$ (PDP20), and $109 \pm 18 \mathrm{~m} / \mathrm{Ma}$ (PDP84) (Table 1). As such, it appears that catchment-wide 

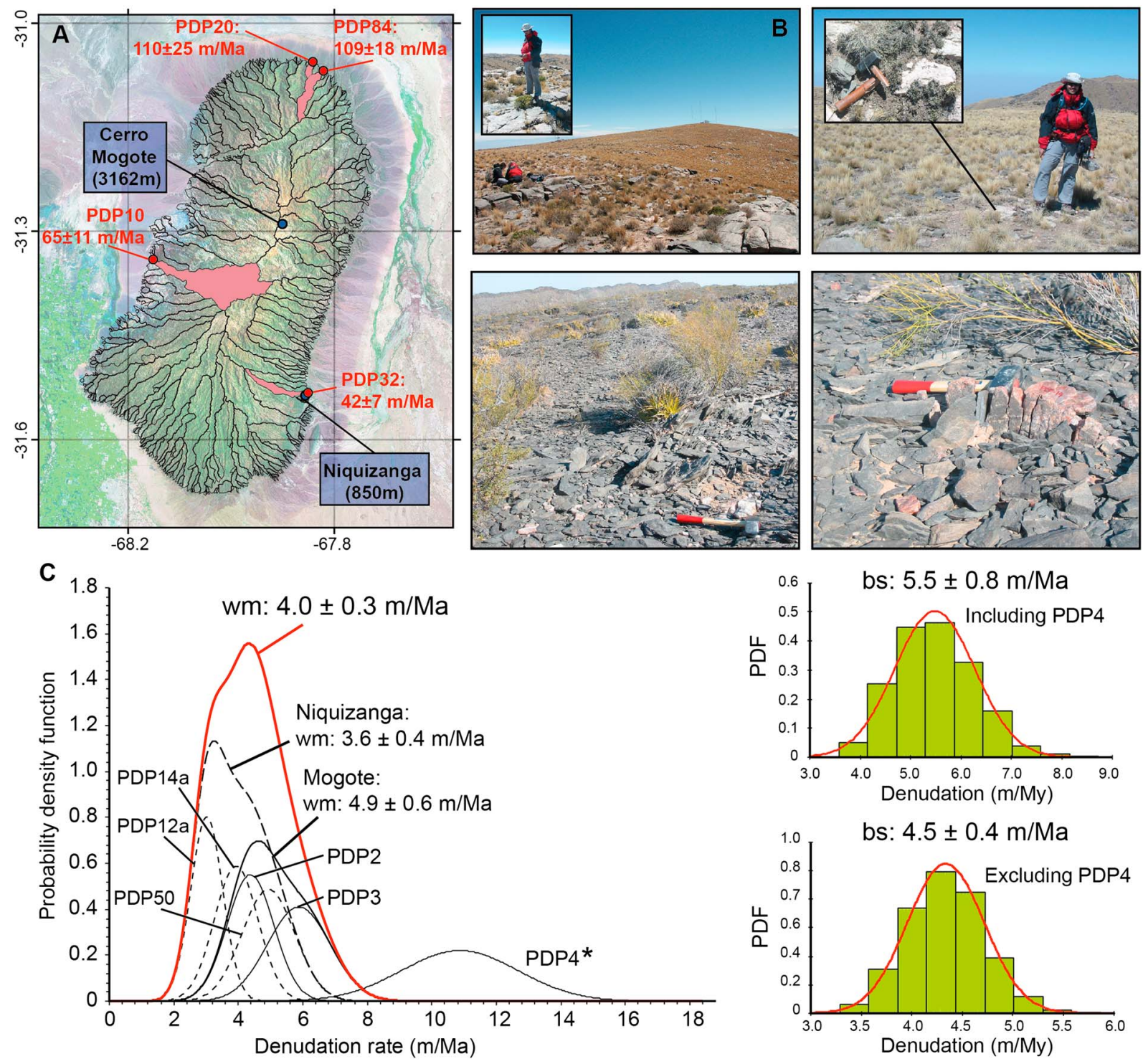

Figure 7. Cosmogenic nuclide-derived denudation rates for Sierra Pie de Palo. (a) Landsat image of the SPDP locating (1) the two bedrock sampling sites (blue solid circles) at Cerro Mogote (3162 m) on top of the surface and at Niquizanga on the southeastern flank of the range, respectively, and (2) the watershed outlets where river-borne sands were sampled (red solid circles, watersheds are highlighted in light red). (b) Field photographs of the sampling site at Cerro Mogote (upper left: PDP2-3; upper right: PDP4) and Niquizanga (lower left: PDP12a; lower right: PDP14a). (c) Statistical analysis of denudation rates obtained for the bedrock samples. Outliers are identified (asterisk); weighted mean (wm) and bootstrap mean (bs) are shown in form of probability function plots (see also supporting information and section 3 ).

denudation rates could be as much as 30 times higher than bedrock denudation rates. Located along the active northern border of the SPDP, samples PDP20 and PDP84 exhibit the highest catchment-wide denudation rates, which is not surprising because their watersheds are more likely to be more rapidly uplifted. When compared to PDP84 and PDP20, sample PDP10 exhibits a catchment-wide denudation rate that is roughly $30 \%$ lower. Another interesting feature is that northern watersheds' catchment-wide denudation rates are apparently not different, whereas the watershed of PDP84 is roughly 4 times larger than that of PDP20 (Table 2). Finally, located along the southeastern border of the SPDP, sample PDP32 exhibits the lowest catchment-wide denudation rate. The difference between the high catchment-wide denudation rates determined along the northern border and that of the PDP32 watershed along the southeastern border might well reflect a difference in tectonic activity between the two areas. 
Table 2. Excavation Times Estimated From Cosmogenic Nuclide-Derived Denudation Rates (Measured Watersheds) $)^{\mathrm{a}}$

\begin{tabular}{|c|c|c|c|c|c|c|c|}
\hline & \multirow{2}{*}{$\begin{array}{l}\text { Volume (Surf-SRTM) } \\
\qquad\left(\mathrm{km}^{3}\right)\end{array}$} & \multirow{2}{*}{$\begin{array}{l}\text { Area } \\
\left(\mathrm{km}^{2}\right)\end{array}$} & \multirow{2}{*}{$\begin{array}{c}\text { Ratio V/S } \\
(\mathrm{km})\end{array}$} & \multicolumn{2}{|c|}{ Denudation (m/Ma) } & \multicolumn{2}{|c|}{ Excavation Time (Myr) } \\
\hline & & & & Value & Error & Value & Error \\
\hline PDP10 & 15.9 & 82.7 & 0.19 & 65 & 11 & 3.0 & 0.5 \\
\hline PDP20 & 0.2 & 2.5 & 0.08 & 110 & 25 & 0.7 & 0.2 \\
\hline PDP32 & 0.4 & 10.0 & 0.04 & 42 & 7 & 0.9 & 0.1 \\
\hline PDP84 & 1.2 & 13.7 & 0.09 & 109 & 18 & 0.8 & 0.1 \\
\hline
\end{tabular}

${ }^{a}$ Minimum eroded volumes are estimated subtracting the present-day topography (SRTM DEM) to the surface envelope model (Figure 2) according to Champagnac et al. [2014]. Watershed areas have been extracted from the digital elevation model (SRTM DEM) using RivertoolsTM software. Denudation rates correspond to cosmogenic nuclide-derived estimates, and excavation times are determined assuming that denudation rates are constant with time.

\subsection{Influence of Denudation Rates on Inferred Tectonic Rates}

In situ-produced ${ }^{10} \mathrm{Be}$ concentrations measured in boulders or cobbles deposited onto the surface of alluvial terraces have been interpreted as minimum exposure ages assuming rapid exposure and no burial or erosion after the beginning of the exposure. As described in sections 5.1 and 5.2, most of the studied alluvial surfaces exhibit the characteristics of deflated stony desert pavements through winnowing with well-developed desert varnish. If the sampled boulders were deposited at the surface of the alluvial terraces during the last alluviation episode before abandonment, they should have remained fully exposed to cosmic rays, even during surface lowering through deflation of the fine materials and compaction of the alluvial material. The denudation rates of about 4-6 m/Ma derived by Hedrick et al. [2013] from two cosmogenic concentration depth profiles within alluvial materials in the Eastern Precordillera actually estimate such a surface lowering rate. Within this context, the denudation processes affecting the exposed boulders themselves should still be regarded as negligible. However, if a denudation rate of about 4-6 m/Ma is considered to be active on the boulders themselves, then those showing CRE ages of roughly 30 ka should be roughly $10 \%$ older, those with CRE ages of 40-60 ka should be roughly 15-20\% older, and those with CRE ages older than 70-90 ka should be $30-40 \%$ older. Under such an assumption, the samples showing CRE ages older than $\approx 140 \mathrm{ka}$ appear saturated from the cosmogenic nuclide production point of view (see supporting information). Finally, the tectonic rates should be lowered by a factor of about $15 \%$ under the assumption that a denudation rate of roughly $5 \mathrm{~m} / \mathrm{Ma}$ applies to the cobbles and boulders themselves.

\section{Discussion}

\subsection{The Pampean Paradox}

In the western SP, there is a paradox between the lack of Cenozoic cooling ages and the structural reconstructions and basin analyses that suggest several kilometers of exhumation [Dávila and Carter, 2013]. Neogene to Quaternary evidence for tectonic activity associated with the Pampean thrusts is described by Costa et al. [2000], Ramos et al. [2002], Richardson et al. [2013], and this study. For example, to the north of the NPF, the first $10 \mathrm{~km}$ below the surface corresponds to the Neogene units of the Bermejo foreland basin [Zapata, 1998]. Therefore, there is a maximum structural relief of about $13 \mathrm{~km}$, assuming that the summit of SPDP was at the same topographic datum as the bottom of the Bermejo basin at the beginning of the Neogene sedimentation [Smalley et al., 1993].

On the other hand, the exhumation of the Pampean ranges have long been studied using multiple thermochronometric methods, including apatite and zircon fission tracks, (U-Th)/He, and zircon U-Pb [Jordan et al., 1989; Coughlin et al., 1998; Sobel and Strecker, 2003; Carrapa et al., 2008; Löbens et al., 2011, 2013a, 2013b; Enkelmann et al., 2014]. In the westernmost SP, no Cenozoic cooling ages have been reported [Jordan et al., 1989; Coughlin et al., 1998; Löbens et al., 2011, 2013b], contrasting with the northern Pampean ranges, where the most recent exhumation episode started during the Miocene and the Pliocene [Sobel and Strecker, 2003; Carrapa et al., 2008]. In the case of the SPDP, Löbens et al. [2013b] used apatite fission track data and (U-Th)/He measurements of zircon and apatite and proposed that its final cooling and exhumation possibly started 
$60 \mathrm{Ma}$ ago in relation with the denudation of a positive topography already existing since the Mesozoic. This most probably reflects that the thermochronological data are insensitive to the most recent phase of relief development in this Andean region.

\subsection{Testing the Pampean Paradox}

The cosmogenic-derived results presented in this study allow constraining the uplift scenario experienced by the SPDP. Indeed, subtracting the present-day topography (SRTM90 DEM) from the fold envelope (Figure 2) allows estimating the minimum volume of rock eroded since the bedrock was uplifted (geophysical relief [e.g., Champagnac et al., 2014]). Assuming that the development of the watersheds has started as soon as the Precambrian rocks reached the surface (once overlying Neogene strata were eroded), durations needed to excavate the eroded volumes can be roughly estimated for each studied watershed assuming constant denudation rates through time (Table 2).

Whether denudation rates integrated over the last 10-100 kyr (this study) can be propagated over much longer periods of time is an important issue. Considering that widespread increases in sediment accumulation have been described at the onset of Quaternary glaciations [Hay et al., 1988; Molnar and England, 1990; Métivier et al., 2002; Molnar, 2004; Zhang et al., 2001; Herman et al., 2013], changes in denudation rates at million year timescales are poorly constrained, and their Plio-Quaternary variability at the global scale is still a matter of debate [Willenbring and von Blanckenburg, 2010; Puchol et al., 2012]. For example, Hidy et al. [2014] showed the low-relief, nonglaciated, and tectonically inactive landscape of interior of Texas to erode more rapidly (30-35\% increase) during interglacial periods in connection with higher temperatures. However, since Plio-Quaternary variability of denudation rates in this Andean region is still unknown, we made the oversimplified assumption that catchment-wide and bedrock cosmogenic-derived denudation rates can be extended over the past few millions of years.

Assuming this simplistic scenario, the time needed to excavate the largest studied watershed (sample PDP10; Quebrada Salinas Grandes) is estimated at 3.0 $\pm 0.5 \mathrm{Ma}$ (Table 2). Interestingly, for both northern and eastern sides of the range, the minimum eroded volumes combined with the catchment-wide denudation rates yield comparable excavation durations of about $1 \mathrm{Ma}$ (Table 2). This link between catchment-wide denudation rates, excavation durations, and drainage basin development can be illustrated by the linear relationship between excavation durations and watershed areas (Figure 8a). Our bedrock samples indicate that up to $4.5 \pm 0.4 \mathrm{~m} / \mathrm{Ma}$ of material was lost by the uplifting bedrock surface, leading to as much as 10 to $18 \mathrm{~m}$ of surface lowering during the last $3.0 \pm 0.5 \mathrm{Ma}$. When integrated over the range, this surface lowering represents approximately $2.4-4.3 \mathrm{~km}^{3}$ and thus only 2 to $3 \%$ of the total $135 \mathrm{~km}^{3}$ minimum eroded volume excavated by fluvial erosion (Figure 2). This estimate led us to consider that the minimum eroded volume determined from the geophysical relief is relatively close to the actual volume of eroded material.

Slope is often considered as one of the main controlling parameters in erosion models [e.g., Champagnac et al., 2014, and references therein]. Despite the limited number of measurements available for the SPDP, the catchment-wide denudation rates increase nonlinearly with slope up to values of roughly $110 \mathrm{~m} / \mathrm{Ma}$ corresponding to an average basin slope of roughly $23^{\circ}$ (Figure 8b). The catchment corresponding to sample PDP20 has a higher average slope $\left(28^{\circ}\right)$, whereas its catchment-wide denudation rate is also of about $110 \mathrm{~m} / \mathrm{Ma}$. However, the drainage area of this particular watersheds is very small with respect to the other studied basins and should not be characterized by sufficient sediment mixing as required to meet with the method's assumptions. Sample PDP20 can thus be regarded as an outlier and discarded from the exponential relationship linking catchment-wide denudation with basin average slope (Figure 8b). Interestingly, the significantly lower maximum denudation rates determined for bedrock outcrops with slopes of 8-10 $0^{\circ}$ are in good agreement with this relationship. This threshold above which denudation no longer scales with slope [e.g., Montgomery and Brandon, 2002; Ouimet et al., 2009] has been described in California [DiBiase et al., 2010], Central Chile [Carretier et al., 2012], and Qilian Shan [Palumbo et al., 2011].

The exponential relationship can be used to model catchment-wide denudation rates from the regional pattern of average basin slope (Figures $8 c$ and $8 d$ ). This operation unveils that most of the watersheds with the highest modeled catchment-wide denudation rates are distributed along the northern and eastern flanks of the SPDP where the master active faults are located (Figure 8e). Therefore, slope, and hence tectonic activity, appears to be the main parameter controlling fluvial-driven erosional and denudation processes in the desert environment of this Andean region. 

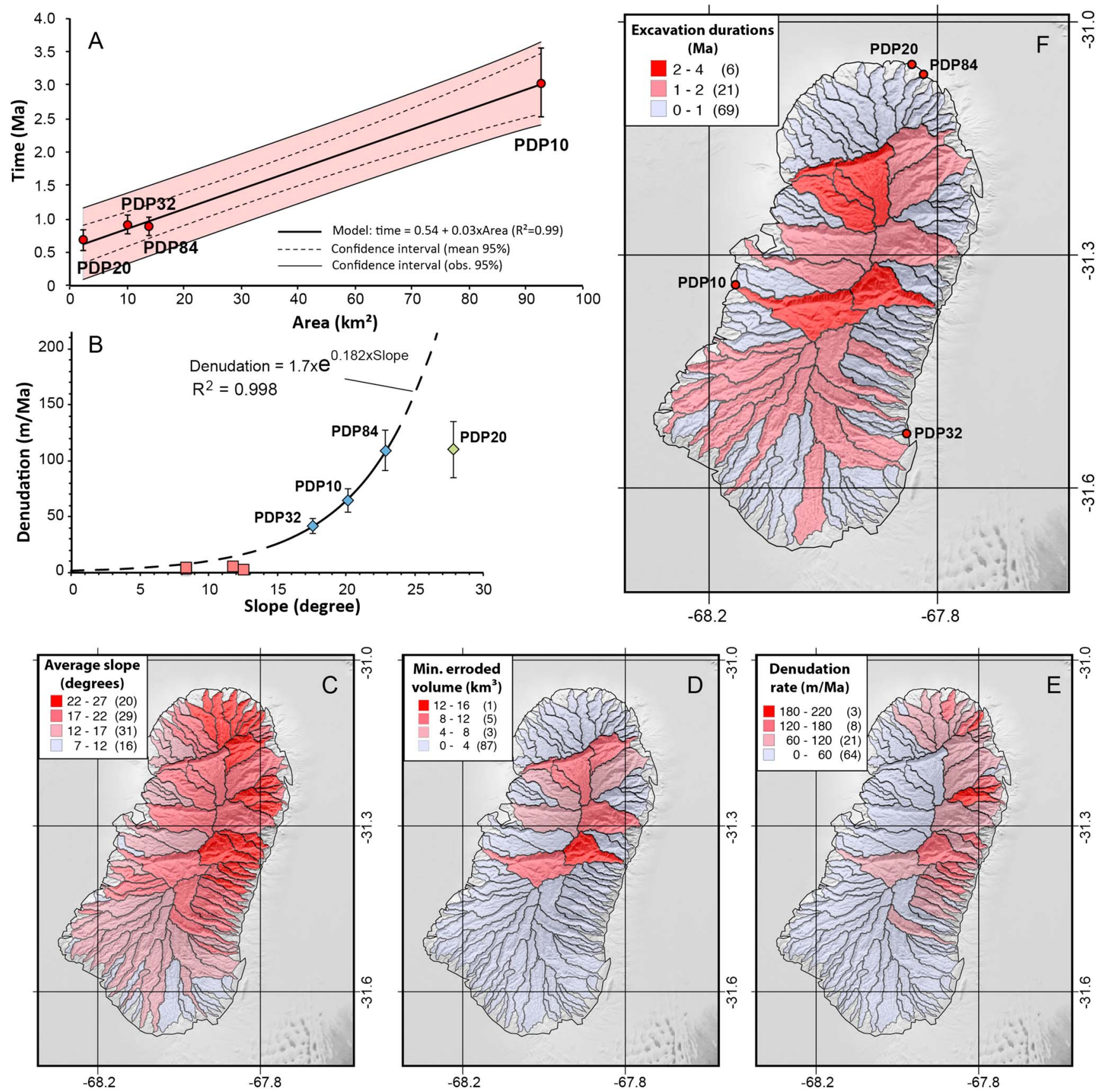

Figure 8. Regional pattern of excavation durations for the Sierra Pie de Palo. (a) Plot diagram showing the linear relationship between excavation durations (determined from cosmogenic nuclide-derived denudation rates and minimum eroded volumes) and watershed areas. (b) Plot diagrams showing the exponential relationship linking denudation rate and the watershed average slope (calculated over the basin area around the sample pixel). (c) Regional pattern of watershed slope averaged over drainage basin area. (d) Minimum eroded volumes determined for each watershed from the spatial integration of vertical incision values (Figure 2e). (e) Denudation rates modeled from the slope-denudation relationship (shown in Figure 8b). (f) Regional pattern of excavation durations derived from the combination of modeled denudation rates (shown in Figure 8e) with minimum eroded volumes for each watershed (shown in Figure 8d).

Combining the regional patterns of denudation rates and the minimum eroded volumes allows us to estimate the durations needed to excavate the largest watersheds at approximately $4 \mathrm{Ma}$ (Figure 8f). However, this first-order estimate should be revised in the future once actual denudation rates characterizing the Early Quaternary and the Pliocene are made available. In addition, accounting for the excavation durations calculated for the studied watersheds (Table 2) and those modeled using the exponential relationship that links 

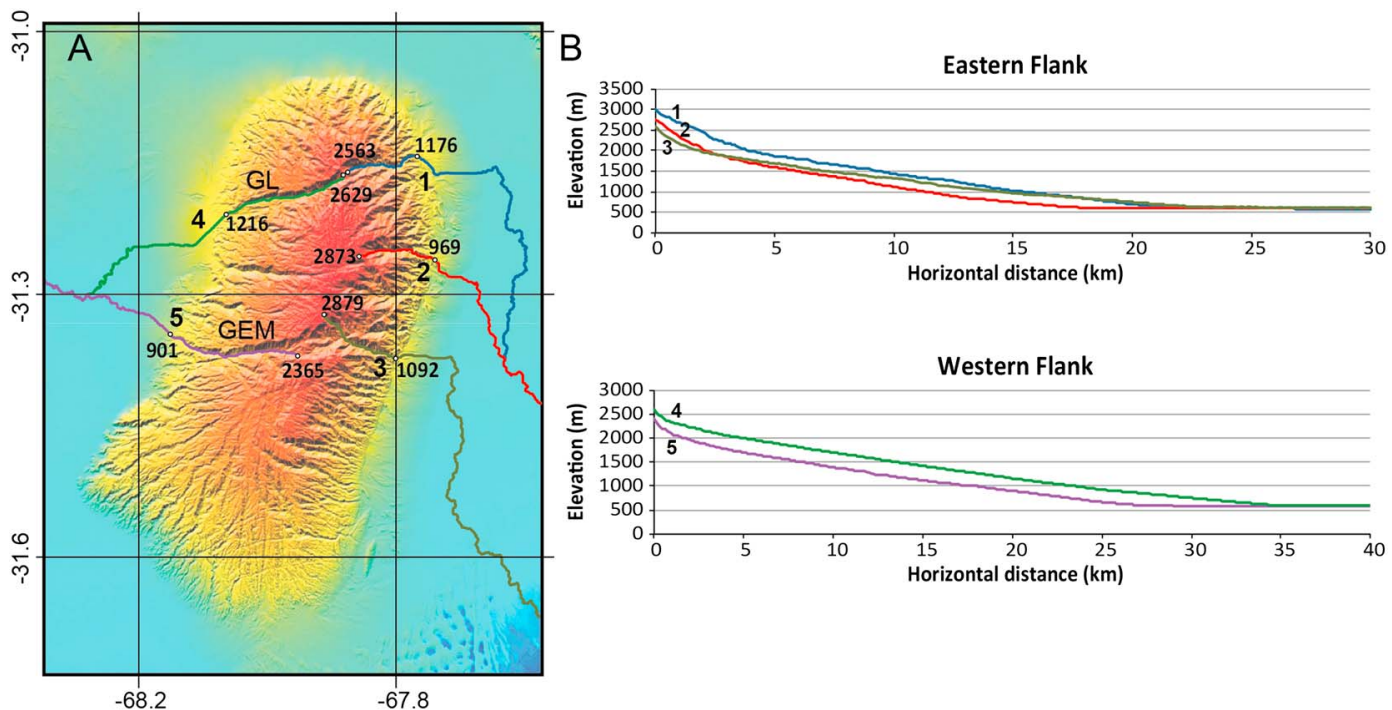

Figure 9. Longitudinal topographic profiles for selected river channels incised into the Sierra Pie de Palo. (a) Map of the SPDP showing the location of the selected river channels (numbered 1 to 5). Numbers give the elevation (in meters) of the headwaters and outlets for selected river channels. (b) Plot diagrams showing the longitudinal topographic profiles of the selected river channels extracted from the SRTM90 DEM using Rivertools software.

denudation and average slope suggest a more recent phase of topographic rejuvenation at roughly $1-2 \mathrm{Ma}$, which could be related to the development of the steeper northern and eastern flanks of the SPDP anticline.

Because cosmogenic-derived denudation rates and eroded volumes are maximum and minimum estimates, respectively, when combined to assess watershed excavation durations, they lead to lower limits. Furthermore, river systems respond transiently to an increase in uplift rate, the hillslope response being delayed after the transient knickpoint has moved upstream and passed over the hillslope base level. Such river adjustment, where the incision rate matches the background uplift rate, can be described by a simple scaling relationship between the upstream change in the channel elevation (dz) from either a knickpoint, if the riverbed is still in a transient state, or from the outlet, if it is fully adjusted [Whipple, 2010; Schildgen et al., 2012]:

$$
\Delta z=\Delta t \cdot\left(U_{f}-U_{i}\right)
$$

where $\Delta t$ is the time elapsed since the change of uplift, $U_{f}$ is the final uplift rate, and $U_{i}$ is the initial uplift rate. Because the vertical accuracy of SRTM DEM is at best on the order of several meters ( $\leq 15-20 \mathrm{~m}$ ) [e.g., Gorokhovitch and Voustianiouk, 2006; Czubski et al., 2013], this relationship was only explored along the major river channels incised into the SPDP. Selected longitudinal topographic profiles do not evidence obvious and significant knickpoints along the course of the river channels (Figure 9), suggesting that these major rivers may have reach equilibrium. The elevation differences measured between headwaters and outlets $(\mathrm{dz})$ range from 1390 to $1900 \mathrm{~m}$ (Figure 9). Constraining the final uplift $\left(U_{f}\right)$ between a lower bound based on the cosmogenic-derived incision rate $(0.4 \pm 0.1 \mathrm{~mm} / \mathrm{yr})$ and an upper bound based on the cosmogenic-derived surface uplift rates $(0.5 \pm 0.2 \mathrm{~mm} / \mathrm{yr})$, and assuming a negligible initial uplift $\left(U_{i}\right)$, the scaling relationship proposed by Whipple [2010] lead to a maximum time elapsed since the beginning of the uplift comprised between 2 and $6 \mathrm{Ma}$. The minimum time durations required to erode the incised volumes estimated from denudation rates may therefore be doubled if transient changes of the watersheds during the uplift must be taken into account.

\subsection{Long-Term, Geomorphic, and Short-Term Tectonic Rates}

The scenario described above favors the hypothesis that the onset of the present-day topography should have occurred during the Pliocene, possibly at 4-6 Ma, providing far greater resolution into the recent landscape evolution than has been possible with thermochronological data [Löbens et al., 2013b]. Actually, Dávila and Carter [2013] proposed that previous interpretation of thermochronological data underestimated the magnitude of rock uplift and exhumation of the Pampean blocks by neglecting the thermal effects of flat slab subduction, which may have substantially depressed the geothermal gradient by removing the mantle wedge [e.g., Collo et al., 2011], and shortened exposure to heating due to rapid Neogene burial and 
subsequent Andean uplift. The relatively deep, $\approx 35 \mathrm{~km}$ seismogenic depth below the westernmost SP [Régnier et al., 1992; Smalley et al., 1993] is also in quite good agreement with a depressed geothermal gradient [Alvarado et al., 2009].

Using a geothermal gradient of $18-23^{\circ} \mathrm{C} / \mathrm{km}$ [e.g., Dávila and Carter, 2013] and a paleosurface temperature of $17^{\circ} \mathrm{C}$ [e.g., Löbens et al., 2013b] implies that an exhumation of 1.9-2.4 km is needed to bring rock cooling from below $60^{\circ} \mathrm{C}$ to the surface. This thickness may represent the Neogene foreland strata that might have covered the SPDP basement [Ramos and Vujovich, 2000; Ramos et al., 2002]. Once the sediment cover was eroded, the basement rocks started experiencing denudation and drainage network development. According to the cosmogenic nuclide-derived denudation rates combined with the minimum eroded volume estimates, this last process may have started at about 4-6 Ma. Buckling of the crust below the SPDP probably started with the inception of rapid exhumation of the basement in the Sierra Valle Fertil system at 10 Ma [Coughlin et al., 1998]. Thus, exhumation of the basement rocks from 1.9-2.4 km to the surface should have taken place during a time span of about 4-6 Ma, leading to an exhumation rate of about $0.3-0.6 \mathrm{~mm} / \mathrm{yr}$, which is roughly 10 times faster than that integrated by Löbens et al. [2013b] over the last $60 \mathrm{Ma}$. As the top of SPDP is presently at an elevation of roughly $3.2 \mathrm{~km}$, towering over a plain standing at $600 \mathrm{~m}$, this also implies a rock uplift of 4.5 to $5.0 \mathrm{~km}$ to be accommodated over the last $10 \mathrm{Ma}$ and thus leads to a long-term uplift rate of approximately $0.5 \mathrm{~mm} / \mathrm{yr}$. Over the last 4-6 Ma, $2.6 \mathrm{~km}$ of rock uplift should have been accommodated at a rate of about $0.4-0.7 \mathrm{~mm} / \mathrm{yr}$. Long-term rock uplift rates estimated over the last 10 to $4 \mathrm{Ma}$ are in good agreement with the surface uplift and incision rates that have been determined on geomorphic time scales at Agua Brava and Niquizanga using offset geomorphic markers and CRE dating.

In this Andean region, Brooks et al. [2003] proposed a craton-fixed velocity field from survey and continuous GPS networks spanning from 1993 to 2001. At a first order, this velocity field is dominated by the elastic loading of the locked subduction interface, with the largest velocities ( $35 \mathrm{~mm} / \mathrm{yr}$ ) being closer to the trench and decreasing cratonward. This GPS study also suggests a possible decrease of the present-day velocities with a maximum of some $5 \mathrm{~mm} / \mathrm{yr}$ to be accommodated by the active faults located between the Eastern Precordillera and Sierra de Valle Fértil. In the Eastern AP, structural and geochronological studies concluded that the Holocene shortening rate associated with the Villicùm-Perdernal Fault should be about $1 \mathrm{~mm} / \mathrm{yr}$ [Siame et al., 2002; Meigs et al., 2006], comparable with the one derived from a paleoseismic study in the Tullum Valley [Rockwell et al., 2014]. As the deformation rates for the SPDP based on offset geomorphic markers along individual faults are also approximately $1 \mathrm{~mm} / \mathrm{yr}$, GPS-derived velocities are thus in good agreement with the tectonic rates integrated over Holocene to Pleistocene time scales.

\section{Conclusions}

In the westernmost SP, the SPDP concentrates most of the regional seismic moment release and plays a key role in the structural evolution of the Andean foreland of northwestern Argentina. In this region, measurement of in situ-produced cosmogenic ${ }^{10}$ Be concentrations allows us to quantitatively constrain the landscape evolution during the Plio-Quaternary in connection with active tectonics linked to mountain building processes and the growth of a large basement anticline. Using a combination of CRE dating of stepped and/or faulted alluvial landforms and detailed topographic analyses, we estimated incision and uplift rates along its major bounding faults.

Along the southeastern border of the SPDP, progressive exhumation of the regional erosion surface combined with climate-driven alluvial deposition constructed a series of stepped alluvial terraces that were abandoned between $31 \pm 3 \mathrm{ka}$ and $132 \pm 15 \mathrm{ka}$. With this new chronological framework, we estimated a minimum slip rate for the EPF of $0.5 \pm 0.1 \mathrm{~mm} / \mathrm{yr}$, with the possibility of a faster rate of $0.8 \pm 0.4 \mathrm{~mm} / \mathrm{yr}$. Along the northern border of the SPDP, the Pajaritos Fault affects a series of alluvial terraces, producing topographic escarpments. Combining CRE dating of the deformed alluvial landforms with topographic measurements of these fault escarpments, we determined a Pleistocene fault slip rate of $1.0 \pm 0.4 \mathrm{~mm} / \mathrm{yr}$, with the possibility of a slower Holocene slip rate of $0.6 \pm 0.4 \mathrm{~mm} / \mathrm{yr}$. The fault slip rates estimated for Holocene to Pleistocene time scales are in good agreement with the $0.5-1 \mathrm{~mm} / \mathrm{yr}$ rate estimated over the last $10 \mathrm{Ma}$ [Zapata and Allmendinger, 1996; Zapata, 1998; Ramos et al., 2002] and compatible with the GPS-derived velocity field [Brooks et al., 2003].

Catchment-wide, cosmogenic nuclide-derived denudation rates combined with watershed geomorphic characteristics allows us to estimate the time span for the development of the river network incising the uplifted and folded erosional surface. In our scenario, 1.9 to $2.4 \mathrm{~km}$ exhumation of the SPDP basement has taken 


\section{Acknowledgments}

The French AMS National Facility ASTER (CEREGE, Aix-en-Provence) is supported by the INSU/CNRS, the ANR through the "Projets thématique d'excellence" Program for the "Equipements d'Excellence" ASTER-CEREGE action, IRD, and CEA. We are grateful to Maurice Arnold, Georges Aumaître, and Karim Keddadouche for their invaluable help during ${ }^{10} \mathrm{Be}$ AMS measurements. We would like to thank Taylor Schildgen and Claudio Faccenna at Tectonics as well as two anonymous reviewers for their insightful comments and suggestions that helped improving our manuscript. SPOT images were provided by the Tectoscope-Andes and ISIS programs (CNES/INSU/CNRS). We thank ECOS-SUD program for travel grants allowed to L. Siame and M. Sébrier for fieldwork in Argentina and for $\mathrm{E}$. Ahumada and $\mathrm{H}$. Cisneros for CRE sample preparation in CEREGE (France). Facilities, equipment, and partial fund for field works were provided by Universidad Nacional de San Luis (project CyT340303). During 2013-2015, L. Siame benefited from a delegation position at CNRS and has been appointed as Visiting Associate Research Fellow at Institute of Earth Sciences, Academia Sinica (NSC 102-2811-M-001 and MOST 103-2811-M-001-135) and Adjunct Professor at National Central University. Users can access the data from the paper via the supporting information associated with this article. This is contribution of the Institute of Earth Sciences, Academia Sinica, IESAS1944. place from 10 to 4-6 Ma, in connection with the westward propagation of the SP and inception of the Eastern AP. This exhumation led the basement rocks to reach the surface at about 4-6 Ma, implying a Pliocene onset of the development of present-day relief. In addition, the SPDP anticline experienced a flank steepening episode above the two major bounding NPF and EPF structures at roughly 1-2 Ma, resulting in the observed geomorphic rejuvenation and asymmetric, arched morphology.

Large earthquakes such as the $M_{w} 7.4,1977$ Caucete event may produce average coseismic displacements of roughly 1.6 to $2.2 \mathrm{~m}$ on a $65 \mathrm{~km}$ long fault dipping between 50 and $60^{\circ}$. Assuming a simplistic pure stick-slip fault behavior and accounting for a fault slip rate ranging from 0.6 to $1 \mathrm{~mm} / \mathrm{yr}$, the recurrence interval for such large earthquakes should be of approximately 2000-4000 years, i.e., similar to that calculated from paleoseismic data for the $M_{w} 7.41944$ San Juan event in the Eastern Precordillera [Rockwell et al., 2014]. Finally, from a regional point of view, active deformation between the eastern front of the Central AP and the SP is thus located on the western edge of the Tullum valley, the SPDP, and the Las Chacras Fault at the toe of the Valle Fértil Fault system.

\section{References}

Alvarado, P., and S. Beck (2006), Source characterization of the San Juan (Argentina) crustal earthquakes of 15 January $1944\left(M_{W} 7.0\right)$ and 11 June $1952\left(M_{W}\right.$ 6.8), Earth Planet. Sci. Lett., 243(3-4), 615-631, doi:10.1016/j.epsl.2006.01.015.

Alvarado, P., S. Beck, G. Zandt, M. Araujo, and E. Triep (2005), Crustal deformation in the south-central Andes back-arc terranes as viewed from regional broad-band seismic waveform modeling, Geophys. J. Int., 163(2), 580-598, doi:10.1111/j.1365-246X.2005.02759.x.

Alvarado, P., S. Barrientos, M. Saez, M. Astroza, and S. Beck (2009), Source study and tectonic implications of the historic 1958 Las Melosas crustal earthquake, Chile, compared to earthquake damage, Phys. Earth Planet. Inter., 175(1), 26-36, doi:10.1016/j.pepi.2008.03.015.

Anderson, M., P. Alvarado, G. Zandt, and S. Beck (2007), Geometry and brittle deformation of the subducting Nazca Plate, Central Chile and Argentina, Geophys. J. Int., 171(1), 419-434, doi:10.1111/j.1365-246X.2007.03483.x.

Arnold, M., S. Merchel, D. L. Bourlès, R. Braucher, L. Benedetti, R. C. Finkel, G. Aumaître, A. Gottdang, and M. Klein (2010), The French accelerator mass spectrometry facility ASTER: Improved performance and developments, Nucl. Inst. Methods Phys. Res. Sec. B: Beam Interact. Mater. Atoms, 268(11-12), 1954-1959.

Balco, G., J. O. Stone, N. A. Lifton, and T. J. Dunai (2008), A complete and easily accessible means of calculating surface exposure ages or erosion rates from ${ }^{10} \mathrm{Be}$ and ${ }^{26} \mathrm{Al}$, Quat. Geochronol., 3, 174-195.

Baldis, B., E. Ulliarte, and A. Vaca (1979), Análisis estructural de la comarca sísmica de San Juan, Rev. de la Asociac. Geol. Argentina, 34, $294-310$.

Bense, F. A., S. Löbens, I. Dunkl, K. Wemmer, and S. Siegesmund (2013), Is the exhumation of the Sierras Pampeanas only related to Neogene flat-slab subduction? Implications from a multi-thermochronological approach, J. South Am. Earth Sci., 48, 123-144, doi:10.1016/j.jsames.2013.09.002.

Braucher, R., S. Merchel, J. Borgomano, and D. Bourlès (2011), Production of cosmogenic radionuclides at great depth: A multielement approach, Earth Planet. Sci. Lett., 309(1-2), 1-9, doi:10.1016/j.epsl.2011.06.036.

Brooks, B. A., M. Bevis, R. Smalley, E. Kendrick, R. Manceda, E. Lauría, R. Maturana, and M. Araujo (2003), Crustal motion in the Southern Andes $\left(26^{\circ}-36^{\circ} \mathrm{S}\right)$ : Do the Andes behave like a microplate?, Geochem. Geophys. Geosyst., 4(10), 1085, doi:10.1029/2003GC000505.

Brown, E. T., J. M. Edmond, G. M. Raisbeck, F. Yiou, M. D. Kurz, and E. J. Brook (1991), Examination of surface exposure ages of Antarctic moraines using in situ produced ${ }^{10} \mathrm{Be}$ and ${ }^{26} \mathrm{Al}$, Geochim. Cosmochim. Acta, 55(8), 2269-2283, doi:10.1016/0016-7037(91)90103-C.

Cahill, T., and B. Isacks (1992), Seismicity and shape of the subducted Nazca Plate, J. Geophys. Res., 97(B12), 17,503-17,529.

Carignano, C., M. Cioccale, and J. Rabassa (1999), Landscape antiquity of the Central-Eastern Sierras Pampeanas (Argentina): Geomorphological evolution since Gondwanic times, Z. Fur Geomorphologie Suppl., 118, 245-268.

Carrapa, B., J. Hauer, L. Schoenbohm, M. R. Strecker, A. K. Schmidt, A. Villanueva, and J. Sosa Gomez (2008), Dynamics of deformation in the northern Sierras Pampeanas: An integrated study of the Neogene Fiambalá basin, NW Argentina, Geol. Soc. Am. Bull., 120, 1518-1543, doi:10.1130/B26111.1.

Carretier, S., et al. (2012), Slope and climate variability control of erosion in the Andes of central Chile, Geology, 41(2), 195-198, doi:10.1130/G33735.1.

Champagnac, J.-D., P. G. Valla, and F. Herman (2014), Late-Cenozoic relief evolution under evolving climate: A review, Tectonophysics, 614 44-65, doi:10.1016/j.tecto.2013.11.037

Chmeleff, J., F. von Blanckenburg, K. Kossert, and D. Jakob (2010), Determination of the ${ }^{10}$ Be half-life by multicollector ICP-MS and liquid scintillation counting, Nucl. Inst. Methods Phys. Res. Sec. B: Beam Interact. Mater. Atoms, 268(2), 192-199.

Collo, G., F. M. Dávila, J. Nóbile, R. A. Astini, and G. Gehrels (2011), Clay mineralogy and thermal history of the Neogene Vinchina Basin, central Andes of Argentina: Analysis of factors controlling the heating conditions, Tectonics, 30, TC4012, doi:10.1029/2010TC002841.

Costa, C., M. N. Machette, R. L. Dart, H. E. Bastias, J. D. Paredes, L. P. Perucca, G. E. Tello, and K. M. Haller (2000), Map and database of quaternary faults and folds in Argentina, U.S. Geol. Surv. Open File Rep., OFR 00-0108, 81 pp., one Map.

Coughlin, T., P. O'Sullivan, B. Kohn, and R. Holcombe (1998), Apatite fission track thermochronology of Sierras Pampeanas central western Argentina: Implications for the mechanism of plateau-uplift in the Andes, Geology, 26, 999-1002.

Czubski, K., J. Kozak, and N. Kolecka (2013), Accuracy of SRTM-X and ASTER elevation data and its influence on topographical and hydrological modeling: Case study of the Pieniny Mts. Poland, J. Geoinformatics, 9(2), 7-14.

Dávila, F. M., and A. Carter (2013), Exhumation and history of the Andean broken foreland revisited, Geology, 41(4), 443-446, doi:10.1130/G33960.1.

Davison, A., and D. Hinkley (1997), Bootstrap Methods and Their Applications, 582 pp., Cambridge Univ. Press, Cambridge, U. K.

DeMets, C., R. G. Gordon, D. F. Argus, and S. Stein (1990), Current plate motions, Geophys. J. Int., 101(2), 425-478, doi:10.1111/j.1365-246X.1990.tb06579.x.

DiBiase, R. A., K. X. Whipple, A. M. Heimsath, and W. B. Ouimet (2010), Landscape form and millennial erosion rates in the San Gabriel Mountains, CA, Earth Planet. Sci. Lett., 289(1-2), 134-144, doi:10.1016/j.epsl.2009.10.036.

Dunne, J., D. Elmore, and P. Muzikar (1999), Scaling factors for the rates of production of cosmogenic nuclides for geometric shielding and attenuation at depth on sloped surfaces, Geomorphology, 27(1-2), 3-11, doi:10.1016/S0169-555X(98)00086-5. 
Efron, B. (1979), Bootstrap methods: Another look at the jackknife, Ann. Stat., 7, 1-26.

Efron, B., and R. Tibshirani (1993), An Introduction to the Bootstrap, 436 pp., Chapman and Hall, Boca Raton, Fla.

Efron, B., and R. Tibshirani (1986), Bootstrap methods for standard errors, confidence intervals, and other measures of statistical accuracy, Stat. Sci., 1(1), 54-75.

Engdahl, E., and A. Villaseñor (2002), International Handbook of Earthquake and Engineering Seismology, 665-XVI pp., International Geophysics, vol. 81, Elsevier, Amsterdam, doi:10.1016/S0074-6142(02)80244-3.

Enkelmann, E., K. D. Ridgway, C. Carignano, and U. Linnemann (2014), A thermochronometric view into an accent landscape: Tectonic setting development, and inversion of the Paleozoic eastern Paganzo basin, Argentina, Lithosphere, 6, 93-107, doi:10.1130/L309.1.

Godard, V., D. L. Bourlès, F. Spinabella, D. W. Burbank, B. Bookhagen, G. B. Fisher, A. Moulin, and L. Leanni (2014), Dominance of tectonics over climate in Himalayan denudation, Geology, 42(3), 243-246.

Gordillo, C. E., and E. Linares (1981), Geocronologia y petrografia de las vulcanitas Terciarias del departamento Pocho, provincia de Cordoba, Rev. de la Asociac. Geol. Argentina, 36(4), 380-388.

Gorokhovitch, Y., and A. Voustianiouk (2006), Accuracy assessment of the processed SRTM-based elevation data by CGIAR using field data from USA and Thailand and its relation to the terrain characteristics, Remote Sens. Environ., 104, 409-415.

Gosse, J., and F. Phillips (2001), Terrestrial in situ cosmogenic nuclides: Theory and application, Quat. Sci. Rev., 20, $1475-1560$.

Hay, W. W., J. L. Sloan II, and C. N. Wold (1988), Mass/age distribution and composition of sediments on the ocean floor and the global rate of sediment subduction, J. Geophys. Res., 93(B12), 14,933-14,940, doi:10.1029/JB093iB12p14933.

Hedrick, K., L. A. Owen, T. K. Rockwell, A. Meigs, C. Costa, M. W. Caffee, E. Masana, and E. Ahumada (2013), Timing and nature of alluvial fan and strath terrace formation in the Eastern Precordillera, Quat. Sci. Rev., 80, 143-168, doi:10.1016/j.quascirev.2013.05.004.

Herman, F., D. Seward, P. G. Valla, A. Carter, B. Kohn, S. D. Willet, and T. A. Ehlers (2013), Worldwide acceleration of mountain erosion under a cooling climate, Nature, 504, 423-426.

Hidy, A. J., J. C. Gosse, M. D. Blum, and M. R. Gibling (2014), Glacial-interglacial variation in denudation rates form interior Texas, USA, established with cosmogenic nuclides, Earth Planet. Sci. Lett., 390, 209-221, doi:10.1016/j.epsl.2014.01.011.

Instituto Nacional de Prevencòn Sísmica (INPRES) (1982), Microzonificaciòn Sísmica del Valle de Tullùm - Provincia de San Juan, Informe Técnico General 5, San Juan.

Instituto Nacional de Prevencòn Sísmica (INPRES) (2014), Terremotos históricos ocurridos en la República Argentina, Instituto Nacional de Prevenciòn Sísmica, San Juan, Argentina. [Available at http://www.inpres.gov.ar/seismology/historicos.html, Access date: October 2014.]

Jackson, J., R. Norris, and J. Youngson (1996), The structural evolution of active fault and fold systems in central Otago, New Zealand: Evidence revealed by drainage patterns, J. Struct. Geol., 18(2), 217-234.

Jackson, J., J. F. Ritz, L. Siame, G. Raisbeck, F. Yiou, R. Norris, J. Youngson, and E. Bennett (2002), Fault growth and landscape development rates in Otago, New Zealand, using in situ cosmogenic ${ }^{10}$ Be, Earth Planet. Sci. Lett., 195(3-4), 185-193.

Jordan, T., J. Allmendinger, R. W. Damanti, and R. E. Drake (1993), Chronology of motion in a complete thrust belt: The Precordillera, 30-31 ${ }^{\circ} \mathrm{S}$, Andes Mountains, J. Geol., 100(2), 135-156.

Jordan, T. E., and R. W. Allmendinger (1986), The Sierras Pampeanas of Argentina: A modern analogue of Rocky Mountain foreland deformation, Am. J. Sci., 286, 737-764.

Jordan, T. E., B. L. Isacks, R. W. Allmendinger, A. J. Brewer, V. A. Ramos, and C. J. Ando (1983), Andean tectonics related to geometry of subducted Nazca plate, Geol. Soc. Am. Bull., 94(3), 341-361, doi:10.1130/0016-7606(1983)94.

Jordan, T. E., P. Zeitler, V. Ramos, and A. J. W. Gleadow (1989), Thermochronometric data on the development of the basement peneplain in the Sierras Pampeanas, J. South Am. Earth Sci., 2(3), 207-222.

Kadinsky-Cade, K., R. Reilinger, and B. Isacks (1985), Surface deformation associated with the November 23, 1977, Caucete, Argentina, earthquake sequence, J. Geophys. Res., 9O(B14), 12,691-12,700, doi:10.1029/JB090iB14p12691.

Kay, S., and J. Abbruzzi (1996), Magmatic evidence for Neogene lithospheric evolution of the central Andean flat-slab between $30^{\circ} \mathrm{S}$ and $32^{\circ}$ S, Tectonophysics, 259(1-3), 15-28, doi:10.1016/0040-1951(96)00032-7.

Kay, S. M., and C. E. Gordillo (1994), Pocho volcanic rocks and the melting of depleted continental lithosphere above a shallowly dipping subduction zone in the Central Andes, Contrib. Mineral. Petrol., 117(1), 25-44.

Kay, S. M., C. Mpodozis, V. A. Ramos, and F. Munizaga (1991), Magma source variations for mid-late Tertiary magmatic rocks associated with a showing subduction zone and thickening crust in the Central Andes $\left(28-33^{\circ} \mathrm{S}\right)$, in Andean Magmatism and Its Tectonic Setting, vol. 26 , edited by R. S. Harmon and C. W. Rapela, pp. 113-137, Geol. Soc. Am., Boulder, Colo.

Korschinek, G., et al. (2010), A new value for the half-life of ${ }^{10}$ Be by heavy-ion elastic recoil detection and liquid scintillation counting, Nucl. Inst. Methods Phys. Res. Sec. B: Beam Interact. Mater. Atoms, 268(2), 187-191.

Lal, D. (1991), Cosmic ray labeling of erosion surfaces: In situ nuclide production rates and erosion models, Earth Planet. Sci. Lett., 104(2-4), 424-439, doi:10.1016/0012-821X(91)90220-C.

Langer, C., and G. Bollinger (1988), Aftershocks of the western Argentina (Caucete) earthquake of 23 November 1977: Some tectonic implications, Tectonophysics, 148(1-2), 131-146, doi:10.1016/0040-1951(88)90166-7.

Langer, C. J., and S. Hartzell (1996), Rupture distribution of the 1977 western Argentina earthquake, Phys. Earth Planet. Int., 94, 121-132.

Löbens, S., E. R. Sobel, F. A. Bense, K. Wemmer, I. Dunkl, and S. Siegesmund (2013a), Refined exhumation history of the Northern Sierras Pampeanas, Argentina, Tectonics, 32, 453-472, doi:10.1002/tect.20038.

Löbens, S., F. A. Bense, I. Dunkl, K. Wemmer, J. Kley, and S. Siegesmund (2013b), Thermochronological constraints of the exhumation and uplift of the Sierra Pie de Palo, NW Argentina, J. South Am. Earth Sci., 48, 209-219.

Löbens, S., F. A. Bense, K. Wemmer, I. Dunkl, C. H. Costa, P. Layer, and S. Siegesmund (2011), Exhumation and uplift of the Sierras Pampeanas: Preliminary implications from K-Ar fault gouge dating and low-T thermochronology in the Sierra de Comechingones (Argentina), Int. J. Earth Sci., 100(2), 671-694.

Losada-Calderón, A., S. McBride, and M. Bloom (1994), The geology and ${ }^{40} \mathrm{Ar} /{ }^{39} \mathrm{Ar}$ geochronology of magmatic activity and related mineralization in the Nevados del Famatina mining district, La Rioja province, Argentina, J. South Am. Earth Sci., 7(1), 9-24, doi:10.1016/0895-9811(94)90030-2.

McIntyre, G. A., C. Brooks, W. Compston, and A. Turek (1966), The statistical assessment of Rb-Sr isochrons, J. Geophys. Res., 71(22), 5459-5468.

Meigs, A., W. Krugh, and C. Schiffman (2006), Refolding of thin-skinned thrust sheets by active basement-involved thrust faults in the eastern Precordillera of western Argentina, Rev. de la Asociac. Geol. Argentina, 61(4), 589-603.

Meigs, A. J., and J. Nabelek (2010), Crustal-scale pure shear foreland deformation of western Argentina, Geophys. Res. Lett., 37, L11304, doi:10.1029/2010GL043220.

Merchel, S., et al. (2008), Towards more precise ${ }^{10} \mathrm{Be}$ and ${ }^{36} \mathrm{Cl}$ data from measurements at the 10-14 level: Influence of sample preparation, Nucl. Inst. Methods Phys. Res. Sec. B: Beam Interact. Mater. Atoms, 266(22), 4921-4926.

Métivier, F., Y. Gaudemer, P. Tapponnier, and M. Klein (2002), Mass accumulation rates in Asia during the Cenozoic, Geophys. J. Int., 137, 280-318. 
Molnar, P. (2009), The state of interactions among tectonics, erosion, and climate: A polemic, Geol. Soc. Am., 19(7), 44-45.

Molnar, P. (2004), Late Cenozoic increase in accumulation rates of terrestrial sediment: How might climate change have affected erosion rates?, Annu. Rev. Earth Planet. Sci., 32, 67-89.

Molnar, P., and P. England (1990), Late Cenozoic uplift of mountain ranges and global climatic change: Chicken or egg?, Nature, $346,29-34$.

Molnar, P., et al. (1994), Quaternary climate change and the formation of river terraces across growing anticlines on the north flank of the Tian Shan, China, J. Geol., 102, 583-602.

Montgomery, D. R., and M. T. Brandon (2002), Topographic controls on erosion rates in tectonically active mountain ranges, Earth Planet. Sci. Lett., 201(3), 481-489.

Nishiizumi, K., M. Imamura, M. W. Caffee, J. R. Southon, R. C. Finkel, and J. McAninch (2007), Absolute calibration of ${ }^{10}$ Be AMS standards, Nucl. Inst. Methods Phys. Res. Sec. B: Beam Interact. Mater. Atoms, 258(2), 403-413.

Ortiz, A., and J. J. Zambrano (1981), La provincia geológica Precordillera oriental, in VIII Congreso Geológico Argentino, vol. 3, edited by VIII Congreso Geológico Argentino, pp. 59-74, Asociación Geológica Argentina, Buenos Aires.

Ouimet, W. B., K. X. Whipple, and D. E. Granger (2009), Beyond threshold hillslopes: Channel adjustment to base-level fall in tectonically active mountain ranges, Geology, 37(7), 579-582.

Palumbo, L., R. Hetzel, M. Tao, and X. Li (2011), Catchment-wide denudation rates at the margin of NE Tibet from in situ-produced cosmogenic ${ }^{10} \mathrm{Be}$, Terra Nova, 23(1), 42-48, doi:10.1111/j.1365-3121.2010.00982.x.

Perucca, L. P., and R. Onorato (2011), Fallas con actividad cuaternaria en el corredor tectónico Matagusanos - Maradona - acequión entre los ríos de la Flecha y del agua, Provincia de San Juan, Rev. de la Asociac. Geol. Argentina, 68(1), 39-52.

Perucca, L. P., and N. Vargas (2014), Neotectónica de la provincia de San Juan, centro-oueste de Argentina, Bol. de la Soc. Geol. Mexicana, 66(2), 291-304.

Puchol, N., et al. (2012), Paleo-denudation rates at the Plio-Pleistocene transition from in situ produced cosmogenic isotopes (10Be): Method and new results from the Tianshan and the Himalayas, Abstract EP53E-1076 presented at 2012 Fall Meeting, AGU San Francisco, Calif., 3-7 Dec.

Rabassa, J., C. Carignano, and M. Cioccale (2010), Gondwana paleosurfaces in Argentina: An introduction, Geociencias, 4, 439-466.

Ramos, V., and G. Vujovich, (2000), Hoja Geológica San Juan, escala 1:250.000, Tech. Rep., Servicio Geológico Minero Argentino Boletìn, Buenos Aires.

Ramos, V. A., E. Cristallini, and D. J. Pérez (2002), The Pampean flat-slab of the Central Andes, J. South Am. Earth Sci., 15(1), 59-78, doi:10.1016/S0895-9811(02)00006-8.

Régnier, M., J. Chatelain, R. Smalley, J. M. Chiu, B. Isacks, and N. Puebla (1992), Seismotectonic of the Sierra Pie de Palo, a basement block uplift in the Andean foreland, Argentina, Bull. Seismol. Soc. Am., 82, 2549-2571.

Reilinger, R., and K. Kadinsky-Cade (1985), Earthquake deformation cycle in the Andean Back Arc, western Argentina, J. Geophys. Res., 90(B14), $12,701-12,712$.

Reuter, H. I., A. Nelson, and A. Jarvis (2007), An evaluation of void filling interpolation methods for SRTM data, Int. J. Geograph. Inform. Sci., 21(9), 983-1008.

Richardson, T., K. D. . Ridgway, H. Gilbert, R. Martino, E. Enkelmann, M. Anderson, and P. Alvarado (2013), Neogene and Quaternary tectonics of the Eastern Sierras Pampeanas, Argentina: Active intraplate deformation inboard of flat-slab subduction, Tectonics, 32, 1-17, doi:10.1002/tect.20054.

Rockwell, T. K., D. E. Ragona, A. J. Meigs, L. a. Owen, C. H. Costa, and E. A. Ahumada (2014), Inferring a thrust-related earthquake history from secondary faulting: A long rupture record of La Laja Fault, San Juan, Argentina, Bull. Seismol. Soc. Am., 104(1), 269-284, doi:10.1785/0120110080.

Schildgen, T. F., D. Cosentino, B. Bookhagen, S. Niedermann, C. Yildirim, H. Echtler, H. Wittmann, and M. R. Strecker (2012), Multi-phased uplift of the southern margin of the Central Anatolian Plateau, Turkey: A record of tectonic and upper mantle processes, Earth Planet. Sci. Lett., $317-318,85-95$.

Schmidt, S., R. Hetzel, J. Khulmann, F. Mingorance, and V. A. Ramos (2011), A note of caution on the use of boulders for exposure dating of depositional surfaces, Earth Planet. Sci. Lett., 302, 60-70.

Schmidt, S., S. Tsukamoto, E. Salomon, M. Frechen, and R. Hetzel (2012), Optical dating of alluvial fan deposits at the orogenic front of the Andean Precordillera (Mendoza, Argentina), Geochronometria, 39, 62-75.

Sobel, E. R., and M. R. Strecker (2003), Uplift, exhumation and precipitation: Tectonic and climatic control of Late Cenozoic landscape evolution in the northern Sierras Pampeanas, Argentina, Basin Res., 15, 431-451, doi:10.1046/j.1365.2117.2003.00214.x.

Siame, L. L., D. L. Bourlès, M. Sébrier, O. Bellier, J. Carlos Castano, M. Araujo, M. Perez, G. M. Raisbeck, and F. Yiou (1997), Cosmogenic dating ranging from 20 to 700 ka of a series of alluvial fan surfaces affected by the El Tigre fault, Argentina, Geology, 25(11), 975-978, doi:10.1130/0091-7613(1997)025<0975:CDRFTK>2.3.CO;2.

Siame, L. L., O. Bellier, M. Sébrier, D. L. Bourlès, P. Leturmy, M. Perez, and M. Araujo (2002), Seismic hazard reappraisal from combined structural geology, geomorphology and cosmic ray exposure dating analyses: The Eastern Precordillera thrust system (NW Argentina), Geophys. J. Int., 150(1), 241-260.

Siame, L. L., O. Bellier, M. Sébrier, and M. Araujo (2005), Deformation partitioning in flat subduction setting: Case of the Andean foreland of western Argentina ( $\left.28^{\circ} \mathrm{S}-33^{\circ} \mathrm{S}\right)$, Tectonics, 24(5), 1-24, doi:10.1029/2005TC001787.

Siame, L. L., O. Bellier, and M. Sébrier (2006), Active tectonics in the Argentine Precordillera and Western Sierras Pampeanas, Rev. de la Asociac. Geol. Argentina, 61(4), 604-619.

Smalley, R., J. Pujol, M. Regnier, J. M. Chiu, J. Chatelain, B. Isacks, M. Araujo, and N. Puebla (1993), Basement seismicity beneath the Andean Precordillera thin-skinned thrust belt and implications for crustal and lithospheric behaviour, Tectonics, 12, 63-76.

Stone, J. O. (2000), Air pressure and cosmogenic isotope production, J. Geophys. Res., 105(B10), 23,753-23,759, doi:10.1029/2000JB900181.

Strahler, A. N. (1952), Hypsometric (area-altitude) analysis of erosion topography, Geol. Soc. Am. Bull., 63, 1117-1142.

Strecker, M. R. (1987), Late Cenozoic landscape development, the Santa Maria Valley, Northwest Argentina, Cornel Univ., Ithaca, N. Y.

Tosselli, A. (1996), Volcanismo Andino, Aceñolaza, F. G., H. Miller, and A. J. Toselli (eds), A25 pp., Geología del Sistema de Famatina, Münchner Geologische Heste.

Tripaldi, A., P. L. Ciccioli, M. S. Alonso, and S. L. Forman (2010), Petrography and geochemistry of late Quaternary dune fields of western Argentina: Provenance of aeolian materials in southern South America, Aeolian Res., 2(1), 33-48, doi:10.1016/j.aeolia.2010.01.001.

Tripaldi, A., L. Net, L. Limarino, S. Marenssi, G. Re, and A. Caselli (2011), Paleoambientes sedimentarios y procedencia de la Formación Vinchina, Mioceno, noroeste de la prov. de La Rioja, Rev. de la Asociac. Geol. Argentina, 56(4), 443-465.

Urbina, N. P., P. Sruoga, and L. Malvicini (1997), Late tertiary gold-bearing volcanic belt in the Sierras Pampeanas of San Luis, Argentina, Int. Geol. Rev., 39(4), 287-306, doi:10.1080/00206819709465272. 
Vergés, J., V. A. Ramos, A. Meigs, E. Cristallini, F. H. Bettini, and J. Cortés (2007), Crustal wedging triggering recent deformation in the Andean thrust front between $31^{\circ} \mathrm{S}$ and $33^{\circ} \mathrm{S}$ : Sierras Pampeanas-Precordillera interaction, J. Geophys. Res., 112, B03S15, doi:10.1029/2006JB004287.

Vita-finzi, C. (2009), Geomorphology Pie de Palo, Argentina: A cataclastic diapir, Geomorphology, 104(3-4), 317-322, doi:10.1016/ j.geomorph.2008.09.006.

Volponi, F., A. Robles, and J. Sisterna (1983), Gravity variations in the epicentral zone of the Caucete earthquake, November 23rd, 1977, Proc of the IAG, V.1, 18th Gen. Assembly, pp. 296-308, Inst. Sismol. Zonda, Univ., Nac. de San Juan, San Juan, Argentina.

Von Gosen, W. (1992), Structural evolution of the Argentine Precordillera: The Rio San Juan section, J. Struct. Geol., 14(6), 643-667.

Ward, G. K., and S. R. Wilson (1978), Procedures for comparing and combining radiocarbon age determinations: A critique, Archaeometry, 20(1), 19-31.

Whipple, K. E. (2010), Fluvial landscape response time: How plausible is steady-state denudation?, Am. J. Sci., 331, 313-325.

Willenbring, J. K., and F. von Blanckenburg (2010), Long-term stability of global erosion rates and weathering during late-Cenozoic cooling Nature, 465, 211-214.

Yáñez, G., G. R. Ranero, R. von Huene, and J. Díaz (2001), Magnetic anomaly interpretation across a segment of the Southern Central Andes $\left(32-34^{\circ} \mathrm{S}\right)$ : Implications on the role of the Juan Fernández Ridge in the tectonic evolution of the margin during the upper Tertiary, J. Geophys. Res., 106, 6325-6345.

Zambrano, J. J., and G. M. Suvires (2008), Actualización en el límite entre sierras Pampeanas occidentales y Precordillera Oriental, en la provincia de San Juan, Rev. de la Asociac. Geol. Argentina, 63(1), 110-116.

Zapata, T. (1998), Crustal structure of the Andean thrust front at $30^{\circ} \mathrm{S}$ latitude from shallow and deep seismic reflection profiles, Argentina, J. South Am. Earth Sci., 11(2), 131-151, doi:10.1016/S0895-9811(98)00006-6.

Zapata, T. R., and R. W. Allmendinger (1996), Growth stratal records of instantaneous and progressive limb rotation in the Precordillera thrust belt and Bermejo basin, Argentina, Tectonics, 15(5), 1065-1083, doi:10.1029/96TC00431.

Zhang, P., P. Molnar, and W. R. Downs (2001), Increased sedimentation rates and grain sizes 2-4 Myr ago due to the influence of climate change on erosion rates, Nature, $410,891-897$ 